\title{
ValpoScholar
}

Valparaiso University Law Review

Volume 48

Number 3 Spring 2014

pp.715-755

Spring 2014

\section{Preliminary Thoughts on an Attorney-Client Privilege for Law Firms: When a Current Client Threatens to Sue the Firm for Malpractice, Does the Privilege Apply to the Firm's Consultation with In-House Counsel about the Potential Claim?}

Edward J. Imwinkelried

Follow this and additional works at: https://scholar.valpo.edu/vulr

Part of the Law Commons

\section{Recommended Citation}

Edward J. Imwinkelried, Preliminary Thoughts on an Attorney-Client Privilege for Law Firms: When a Current Client Threatens to Sue the Firm for Malpractice, Does the Privilege Apply to the Firm's Consultation with In-House Counsel about the Potential Claim?, 48 Val. U. L. Rev. 715 (2015).

Available at: https://scholar.valpo.edu/vulr/vol48/iss3/8

This Article is brought to you for free and open access by the Valparaiso University Law School at ValpoScholar. It has been accepted for inclusion in Valparaiso University Law Review by an authorized administrator of ValpoScholar. For more information, please contact a ValpoScholar staff member at scholar@valpo.edu. 
Imwinkelried: Preliminary Thoughts on an Attorney-Client Privilege for Law Firm

\title{
PRELIMINARY THOUGHTS ON AN ATTORNEY-CLIENT PRIVILEGE FOR LAW FIRMS: WHEN A CURRENT CLIENT THREATENS TO SUE THE FIRM FOR MALPRACTICE, DOES THE PRIVILEGE APPLY TO THE FIRM'S CONSULTATION WITH IN- HOUSE COUNSEL ABOUT THE POTENTIAL CLAIM?
}

\author{
Edward J. Imwinkelried
}

\section{INTRODUCTION}

Ideally, the attorney-client relationship is supposed to be cooperative and trusting. On one side, the client approaches the attorney, describes his or her legal problem, and discloses their hoped-for outcome in the transaction or litigation. In addition, the client reveals to the attorney all the facts relevant to the transaction or litigation. For his or her part, after carefully evaluating the facts and researching the pertinent law, the attorney gives the client legal advice about the problem. Trusting the attorney, the client accepts the attorney's advice. The client and attorney then work together to achieve the client's desired outcome.

Although the preceding paragraph describes the ideal, in many cases the ideal does not match the reality. In numerous cases, to a degree, the relationship becomes adversary. ${ }^{1}$ The client either sues the attorney for malpractice or threatens to do so. ${ }^{2}$ For decades, the American Bar Association ("A.B.A.") has closely monitored the number of malpractice claims filed against practitioners. Its Standing Committee on Lawyers' Professional Responsibility has collected data from attorneys' liability insurers for 1985, 1995, 1999, 2003, 2007, and, most recently, 2011. ${ }^{3}$ The

Edward L. Barrett, Jr. Professor of Law, University of California, Davis; former chair, Evidence Section, American Association of Law Schools; author, THE NEW WIGMORE: A TREATISE ON EVIDENCE: EVIDENTIARY PRIVILEGeS (Richard D. Friedman ed., 2d ed. 2010). The author would like to express his gratitude to Professor Richard Underwood of the University of Kentucky School of Law and Mr. Charles Mokriski of the Proskauer firm who kindly assisted the author in the preparation of this Article.

1 See, e.g., St. Simons Waterfront, LLC v. Hunter, Maclean, Exley \& Dunn, P.C., 746 S.E.2d 98, 109 (Ga. 2013) (recognizing that "once the relationship between the attorney and client develops into an adversarial one" certain privileges attach).

2 Elizabeth Chambliss, The Scope of In-Firm Privilege, 80 Notre DAME L. REV. 1721, 1721 (2005) (recognizing "the growing incidence of claims against lawyers").

3 JASON T. VAIL \& KATHLEEN MARIE EWIns, AM. BAR Ass'N, STANDing COMM. ON LAWYERS' Prof'L Liab., PROFILE Of LeGAL MALPRACTICE Claims 2008-2011, at 1 (2012).

715 
Valparaiso University Law Review, Vol. 48, N0. 3 [2015], Art. 8

most recent 2011 study covered 2008 through 2011, years affected by the "turbulent... adverse economic climate" in the United States. ${ }^{4}$ That study found that the total number of malpractice claims reported jumped by over 30\% between 2007 and 2011..$^{5}$ Many of the leading liability insurers have become so concerned that they strongly recommend to their insured law firms that the firm appoint an experienced in-house counsel to advise firm members on issues such as malpractice and compliance with ethical standards. ${ }^{6}$

Suppose that during the representation of an outside client plaintiff, the trial judge dismisses one count in the complaint on the ground that the firm did not file the count stating that cause of action within the period of limitations. ${ }^{7}$ While the firm is seeking to persuade the judge to reconsider the ruling, the client expresses its displeasure with the ruling. The client does not immediately terminate the firm. Yet, the client grumbles, suggesting that it is considering suing the firm for professional negligence. At the suggestion of its liability insurer, the firm in question has designated one of its partners as in-house counsel. At this point the firm members representing the plaintiff consult with their in-house counsel about the potential malpractice claim. The firm maintains internal records documenting the consultations.

Several things are clear. To begin, if a non-client subsequently sought discovery of the records, the case law would generally allow the client and the law firm to assert the privilege against the non-client. ${ }^{8}$ By way of example, assume that the defendant in the original lawsuit demanded that the firm produce the written communications between the firm members and the in-house counsel. Both the firm and its outside client could object to production on the ground that the writings are privileged. ${ }^{9}$

\footnotetext{
Id.

See id. at 5 (stating that the participating insurers reported 40,486 claims in 2007 and 52,982 claims in 2011).

Chambliss, supra note 2, at 1722, 1758-59.

See Samson Habte, Law Firms Hopeful About Pending Rulings in Closely Watched 'Intrafirm Privilege' Cases, 81 U.S. L. Wk. (BNA No. 47) 1760, 1761 (June 11, 2013), available at http:/ / news.bna.com/lwln/LWLNWB/split_display.adp?fedfid=32048699\&vname=lw1n otallissues\&jd=a0d9f $2 \mathrm{~m} 7 \mathrm{~b} 4 \&$ split=0 (describing a similar hypothetical scenario discussed by a panel at the 39th American Bar Association ("A.B.A.") National Conference of Professional Responsibility).

8 See Chambliss, supra note 2, at 1730-33 (providing a series of case illustrations on this issue). "Taken together, the nonclient cases offer broad protection for in-firm communication under the attorney-client privilege." Id. at 1732.

9 As holder, the client may assert the privilege in its own right; and the lawyer has implied authority to assert the privilege on the client's behalf. See 1 EDWARD J. ImWinKelried, The NeW Wigmore: A TREatise ON Evidence: EVIDENTIARy PRIVILEges
} 


\section{4] Preliminary Thoughts on an Attorney-Client Privilege 717}

Suppose alternatively that the plaintiff client discharged the firm and either sued the firm for malpractice or threatened to do so. In these circumstances, if the firm later consulted either its in-house counsel or another firm about the potential malpractice claim, the privilege would attach to the consultations. The firm and its former client now stand in a normal adversarial relationship; and, after its termination by the outside client, the firm has a perfect right to seek counsel to prepare a defense against the former client's malpractice claim. However, one key issue is unsettled. Suppose that while the firm continues to represent the outside client, the firm members representing the outside client consult the inhouse counsel about the potential malpractice suit and, after the termination of the relationship, the former client sues and seeks production of the writings reflecting the consultation. In this variation of the fact situation, may the firm assert the attorney-client privilege against its former client?

That issue has produced a sharp split of authority. There are relatively few published decisions on point to provide a firm with guidance. ${ }^{10}$ Worse still, the authorities are badly divided. ${ }^{11}$ "For over two decades, courts routinely rejected law firms' efforts to shield internal communications about potential malpractice liability from their clients."12 However, beginning in the mid-1990s, a counter-trend developed. ${ }^{13}$ In 2013, two state courts, the Georgia Supreme Court and

$\S 6.5 .3$, at 664-65 (Richard D. Friedman ed., 2d ed. 2010) (discussing the U.S. Supreme Court's decision in Swidler \& Berlin v. United States to illustrate this point).

10 See Chambliss, supra note 2, at 1723 ("There are, so far, three cases on the subject...."); Cathryn M. Sadler, Note, The Application of the Attorney-Client Privilege to Communications Between Lawyers Within the Same Firm: Evaluating United States v. Rowe, 30 ARIZ. ST. L.J. 859, 860, 872-73 (1998) (denoting "a lack of authority" on this issue and providing some limited case illustrations); Gail Diane Cox, Court Expands Client Privilege: Associates Are Deemed Counsel for Their Own Firms, NAT'L L.J., Oct. 14, 1996, at A6 (denoting a "dearth of authority'" on the issue based on commentary rather than precedent). In RFF Family Partnership, LP v. Burns \& Levinson, LLP, the court remarked that it found itself in relatively "'uncharted jurisprudential waters."” 991 N.E.2d 1066, 1070 (Mass. 2013) (quoting Hunter, Maclean, Exley \& Dunn, P.C. v. St. Simons Waterfront, LLC, 730 S.E.2d 608 (Ga. Ct. App. 2012)).

11 St. Simons Waterfront, LLC v. Hunter, Maclean, Exley \& Dunn, P.C., 746 S.E.2d 98, 104 (Ga. 2013) (discussing the divide in case law over a law firm's ability to claim attorneyclient privilege for communications with its in-house counsel).

12 Habte, supra note 7, at 1761.

13 See Sadler, supra note 10, at 860 ("United States v. Rowe, was one of the first cases to tackle the issue of intra-firm privilege... finding that communications between lawyers within a firm could be protected by the [attorney-client] privilege." (footnote omitted)). The Ninth Circuit handed down the decision in Rowe in 1996. United States v. Rowe, 96 F.3d 1294 (9th Cir. 1996). 
Valparaiso University Law Review, Vol. 48, N0. 3 [2015], Art. 8

718

the Massachusetts Supreme Judicial Court, ${ }^{14}$ joined the ranks of the minority of jurisdictions permitting the firm to assert the privilege against its former client. ${ }^{15}$

At first blush, a non-lawyer might be outraged at the notion of allowing a law firm to shield documents generated during its representation of an outside client from that client. It may appear that the firm's ethical duty of loyalty to a current client should trump the firm's evidentiary privilege. However, the thesis of this Article is that the Georgia and Massachusetts courts came to the right result.

Part II of this Article is descriptive, surveying the current split of authority. ${ }^{16}$ In contrast, Part III and Part IV of the Article are evaluative. ${ }^{17}$ Part III addresses the merits of the threshold policy question of whether a law firm should ever be permitted to invoke the attorney-client privilege to shield in-house consultations about a client's potential malpractice claim from the outside client. ${ }^{18}$ Part III argues that the courts subscribing to the majority view have misconstrued the case law on the so-called fiduciary exception to the attorney-client privilege. ${ }^{19}$ Part III concludes that at least in some circumstances, a firm has the right to invoke the privilege against its former client. ${ }^{20}$

Next, Part IV attempts to define the circumstances in which courts should uphold an intra-firm privilege against a former client. ${ }^{21}$ In particular, Part IV analyzes the thorny question of whether the privilege attaches to the firm's in-house consultations even when the firm engages in such consultations without the outside client's consent. ${ }^{22}$ Part IV contends that the courts requiring the outside client's consent have misconceived an evidence issue as an ethics question. ${ }^{23}$

This Article does not purport to offer a definitive resolution of these issues. Given the paucity of authority on point and the most recent decisions from Georgia and Massachusetts, it would be presumptuous to

\footnotetext{
14 St. Simons Waterfront, LLC, 746 S.E.2d at 102; RFF Family P'ship, LP, 991 N.E.2d at 106768.

15 See RFF Family P'ship, LP, 991 N.E.2d at 1078-79 (citing other jurisdictions' decisions on the issue and explaining its opposing conclusion); Robert L. Byman, So, You've Screwed Up. Now What? NAT'L L.J., (Jan. 13, 2014), http://www.nationallawjournal.com/id=12 02637723731/So-Youve-Screwed-Up-Now-What\%3Fmcode=0\&curindex=0\&curpage=ALL (discussing the Georgia and Massachusetts decisions).

16 See infra Part II.

See infra Parts III-IV.

See infra Part III.

See infra Part III.A.

See infra Part III.B.

See infra Part IV.

See infra Part IV.B.

See infra Part IV.B.2.
} 
claim to be able to do so. However, the prevalence of legal malpractice claims makes these issues critical to both the bar and its clientele. The intent of this Article is to promote a deeper, more robust debate between the proponents of the traditional majority and emerging minority views.

\section{A DESCRIPTION OF THE PRESENT SPLIT OF AUtHORITY OVER THE QUESTION OF THE FIRM'S RIGHT TO ASSERT THE ATTORNEY-CLIENT PRIVILEGE FOR ITS IN-HOUSE CONSULTATIONS ABOUT A POTENTIAL MALPRACTICE ClAim BY A THEN CURRENT CLIENT}

As Part I noted, there is presently a split of authority over the issue of a firm's ability to invoke the attorney-client privilege to shield inhouse consultations about a possible malpractice action by a then current client. First, Part II.A discusses the traditional view denying the firm the right to assert the privilege. ${ }^{24}$ Second, Part II.B explains the minority view giving the firm the right to assert the privilege. ${ }^{25}$

A. The Traditional, Majority View Denying the Firm the Right to Assert the Privilege Against Its Former Outside Client

The majority view is that the firm cannot assert the attorney-client privilege against its former client. ${ }^{26}$ For decades, "[a] nearly unbroken line of cases" adopted this view. ${ }^{27}$ Some of these cases went to the length of announcing that the firm could not invoke the privilege against the former client "under any circumstances." 28 First, this section discusses state authority in this regard. ${ }^{29}$ It then goes on to explain the federal authority supporting this view..$^{30}$

\section{State Authority}

There is both state and federal support for the majority view. A depublished California decision, McCormick v. Superior Court, ${ }^{31}$ illustrates many courts' reluctance to allow a privilege to attach to a firm's in-house

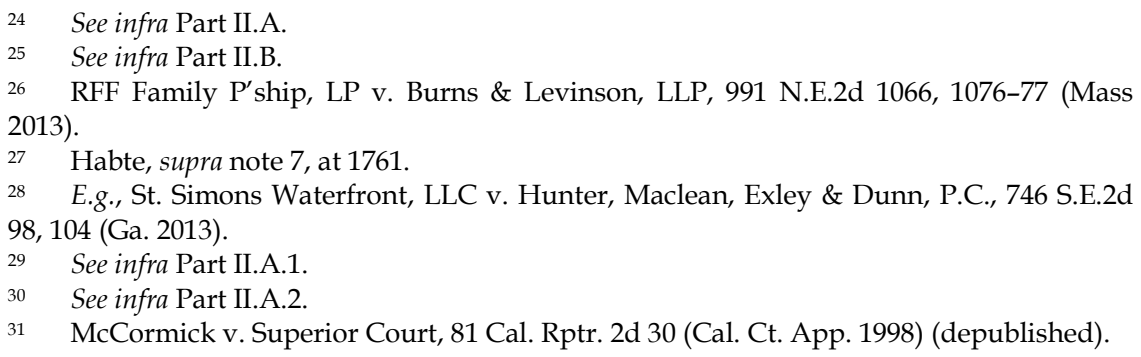


consultations against a then current client. ${ }^{32}$ In McCormick, the client, Nelson, made noises suggesting that he might sue the firm. ${ }^{33}$ At that juncture, the firm hired and consulted with outside counsel about the potential claim. ${ }^{34}$ In addition, the firm members working on Nelson's case consulted with Whitney, a member of the firm's own management committee. ${ }^{35}$ Nelson subsequently sued the firm. ${ }^{36}$ During pretrial discovery, Nelson demanded production of a number of the firm's documents. ${ }^{37}$ The requested documents included writings reflecting consultations between the firm members representing Nelson and Whitney. ${ }^{38}$ The firm cited the attorney-client privilege as the basis for its refusal to produce. ${ }^{39}$ To support its objection, the firm submitted Whitney's declaration to the effect that Whitney and the consulting firm members created the documents "for the ultimate use of [the firm] in representing its own interests and other counsel ultimately retained by [the firm] in the event that [the client] did file a lawsuit." 40

The intermediate appellate court in California rejected the firm's argument. ${ }^{41}$ The court professed that it could not understand how the firm could simultaneously be both the attorney for Nelson and a client with a privilege against Nelson: "If the McCormick firm was the client, who was its lawyer? And who was the client communicating with?" 42 The court characterized the firm's position as a contention that "its internally generated documents [were] ... privileged 'communications' with its lawyer, i.e., with itself." 43 Instead, the court concluded that the communications between Whitney and the firm members working on Nelson's case did not qualify as "confidential communications between a client and a client's lawyer." 44

It is true that in some passages, the court seemed to stop short of adopting a sweeping holding that a firm could never invoke a privilege against a litigant who was a firm client at the time of the

\footnotetext{
32 See Barbara S. Gillers, Preserving the Attorney Client Privilege for Advice of a Law Firm's In-House Counsel, 2000 PROF. LAW.: SYMPOSIUM ISSUE 107, 110-11 (2000) (discussing the court's holding in McCormick). 
communications. ${ }^{45}$ However, in other passages the court employed broad language implying that the court would never entertain an attorney-client privilege claim for intra-firm communications about a potential malpractice claim by a then current client. ${ }^{46}$

2. Federal Authority

There are also several federal opinions lending support to the majority view. ${ }^{47}$ One of the most cited federal opinions is the 1989 decision by the Eastern District of Pennsylvania in In re Sunrise Security Litigation. ${ }^{48}$ Sunrise was the seminal decision applying the so-called "fiduciary duty exception" to the privilege in this context. ${ }^{49}$ In Sunrise, a law firm had represented a failed savings and loan association (Sunrise). ${ }^{50}$ The firm was joined as a defendant with the association in an action by both the association's former shareholders and the government. ${ }^{51}$ When the plaintiffs sought production of some of the firm's internal work documents concerning the firm's representation of the association, the firm objected on privilege grounds. ${ }^{52}$

Unlike the McCormick court, the court was willing to accept the generalization that "'a law firm may consult its own attorneys as house counsel to secure legal advice in connection with or related to the firm's representation of a client, and as a result obtain the protection of the attorney client privilege on the basis that it is its own client.'" 53 The court stated that it was "not willing to hold that a law firm may never make privileged communications with [its own] in house counsel." 54 However, the court then carved out an important exception to the generalization - citing the state rule modeled after A.B.A. Model Rule of Professional Responsibility 1.7 on a lawyer's duty of loyalty, the court asserted that applying the privilege to the firm's in-house consultations

45 See $i d$. at 111 (noting the court's remark that the firm had not taken any clear, definitive steps to sufficiently differentiate normal intra-firm communications from the communications between Whitney and the firm members representing Nelson).

46 See id. at 110 ("If the McCormick firm was the client, who was its lawyer? And who was the client communicating with?").

47 See, e.g., Thelen Reid \& Priest LLP v. Marland, No. C 06-2071 VRW, 2007 WL 578989, at *7 (N.D. Cal. Feb. 21, 2007) (refusing to follow a strict rule "requiring disclosure of all communications relating to a client").

$48 \quad 130$ F.R.D. 560 (E.D. Pa. 1989).

49 Habte, supra note 7, at 1761.

50 Sadler, supra note 10 , at 871.

51 Id.; In re Sunrise, 130 F.R.D. at 562.

52 In re Sunrise, 130 F.R.D. at 562-63.

53 Id. at 594-95.

54 Id. at 595 . 
could conflict with the firm's fiduciary duty to the then current client. ${ }^{55}$ The court stated that given the firm's ethical duties, the privilege would not attach to "communications or legal advice in which [the firm's] representation of itself violated Rule 1.7."56 In the court's mind, if the firm's in-house consultation created a conflict of interest between the firm's interests and those of the outside client, the privilege must yield. As in the case of the McCormick decision, the Sunrise opinion mentioned facts suggesting a more limited holding. ${ }^{57}$ However, the Sunrise court's assertion of the fiduciary exception was so forceful that the exception seemed expansive enough to virtually swallow up the generalization.

After Sunrise, "the current-client issue lay dormant until two cases decided in 2002." 58 One decision was Bank Brussels Lambert v. Credit Lyonnaise (Suisse), S.A.59 The firm, Rogers \& Wells, represented Credit Lyonnaise (CL) in certain oil transactions and related litigation. ${ }^{60}$ During the representation, CL told Rogers \& Wells that if CL were found liable in the litigation, in turn CL would attempt to hold Rogers \& Wells liable. ${ }^{61}$ After CL's statement, the firm member heading Roger \& Wells' Clients and Ethics Committee conducted an interval review of the firm's representation of CL. ${ }^{62}$ Later CL fired Rogers \& Wells and sued the firm for malpractice. ${ }^{63}$ In the suit, CL sought production of the documents reflecting the firm's internal review. ${ }^{64}$ As in McCormick and Sunrise, the firm cited the attorney-client privilege as a ground for objecting to the production request. 65

The court overruled the objection. ${ }^{66}$ The court relied on Sunrise as precedent. ${ }^{67}$ The court reasoned that since CL "was still its client" at the time of the internal review, the firm was "in no position to claim a privilege against their client. While the privilege will be applicable against all the world, it cannot be maintained against" CL. ${ }^{68}$ The court

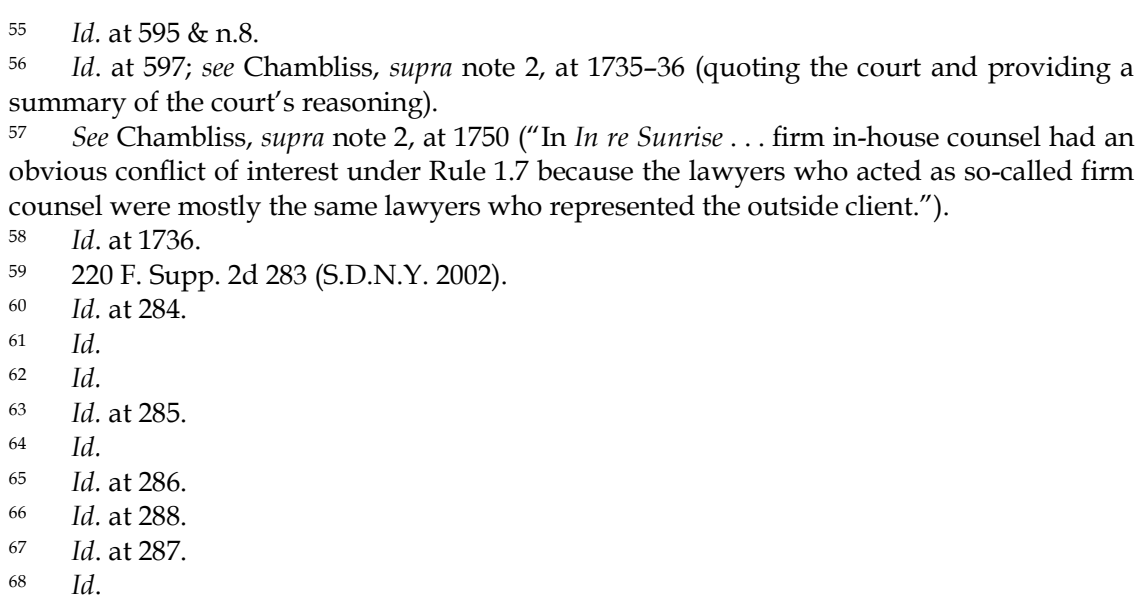




\section{4] Preliminary Thoughts on an Attorney-Client Privilege 723}

underscored the firm's fiduciary duty of loyalty to its outside client at the time of the in-house consultation. ${ }^{69}$ The court asserted flatly that "a law firm cannot invoke the attorney-client privilege against a current client when performing a conflict check in furtherance of representing that client."70 Once again, some commentators have argued that the Bank Brussels ruling could be limited to the peculiar facts of the case. ${ }^{71}$ However, on its face the opinion reads as a ringing endorsement of the fiduciary duty exception announced in Sunrise. ${ }^{72}$

The second noteworthy 2002 decision was Koen Book Distributors $v$. Powell, Trachtman, Logan, Carrle, Bowman E Lombardo, P.C. ${ }^{73}$ The plaintiff book company had hired the defendant firm for advice pertaining to a security interest from one of the company's customers, Crown Books Corporation. $^{74}$ When Crown Books filed for bankruptcy, the firm represented Koen in the bankruptcy proceedings. ${ }^{75}$ However, Koen became dissatisfied with the quality of the firm's services and informed the firm that it was considering filing a malpractice action. ${ }^{76}$ Ultimately, Koen terminated the firm's services in mid-August 2001.77 However, in the interim the firm's lawyers representing Koen consulted another firm member about the "ethical and legal issues that had arisen out of the

\section{Id.}

Id. at 288 .

E.g., Chambliss, supra note 2, at 1750-51. Professor Chambliss has proposed two different bases for a narrow reading of the holding. One is that the firm member who headed the Clients and Ethics Committee "was not formally designated or compensated as in-house counsel." Id. at 1750. The second is that the facts suggest that one of the purposes of the consultation was the unethical objective of concealing the conflict from the client. Id. at 1751. If that had been the firm's objective, the crime/fraud exception to the attorneyclient privilege might come into play. Id. See generally 2 EDWARD J. IMWINKELRIED, THE NeW Wigmore: A TREATISE ON EVIDENCE: EVIDENTIARY PRIVILEgES § 6.13.2.d, at 1166-99 ( $2 \mathrm{~d}$ ed. 2010) (providing an in-depth overview of the crime-fraud exception).

72 Given the nature of the fact situation, the reader might wonder why the court did not uphold the privilege on the ground that the party seeking discovery was a non-party. As Part I pointed out, as a general proposition even the courts rejecting the assertion of the privilege against the client at the time of the communication ordinarily sustain privilege claims against third parties. See Chambliss, supra note 2, at 1732-33 (explaining the scope of the privilege regarding non-clients). However, as previously stated, one of the plaintiffs in the instant case was a group of shareholders. The courts sometimes treat shareholders as representatives of the corporate entity. Id. at 1733-34 (citing Garner v. Wolfinbarger, 430 F.2d 1093 (5th Cir. 1970)). Thus, since the defendant had represented the corporate entity, the court might have conceived the case as a dispute between representatives of the client (the shareholders) and the client's attorney (the law firm).

73212 F.R.D. 283 (E.D. Pa. 2002).

74 Id. at 284

75 Id.

76 Id.

77 Id. 
portent of a malpractice action."78 Those consultations generated a number of internal firm documents. ${ }^{79}$ Koen later sued the firm for malpractice. ${ }^{80}$ During discovery, Koen demanded that the firm produce those documents. ${ }^{81}$ The firm resisted, citing the attorney-client privilege as the justification for its refusal. ${ }^{82}$

Like the other 2002 decision, Bank Brussels, the Koen court turned to Sunrise as authority. ${ }^{83}$ The court declared:

[A] law firm owes a fiduciary duty to a client and may not engage in conflicting representations absent the exceptions set forth in Rule 1.7 of the Pennsylvania Rules of Professional Conduct. Otherwise, to the extent that the seeking or obtaining of legal advice by one lawyer from another lawyer inside the firm "implicates or creates a conflict of interest," the attorney-client privilege between the lawyers is vitiated. ${ }^{84}$

According to the court, the conflict negates the privilege. ${ }^{85}$ The court found that the firm was "engaged in a conflict of interest... when it was receiving information from and/or providing legal advice to several of its lawyers while at the same time continuing to represent" Koen. ${ }^{86}$ Weighing the competing interests of the client and firm, the court decided that the firm's fiduciary duty to its client was "paramount." 87 The court acknowledged that its ruling placed the firm "in an unenviable situation." 88 However, the court reasoned that if the firm neither withdrew from representing the outside client nor obtained the client's consent to the in-house consultations about the client's potential claim, the firm had to "forego the benefit of the attorney-client privilege ... during this period." 89

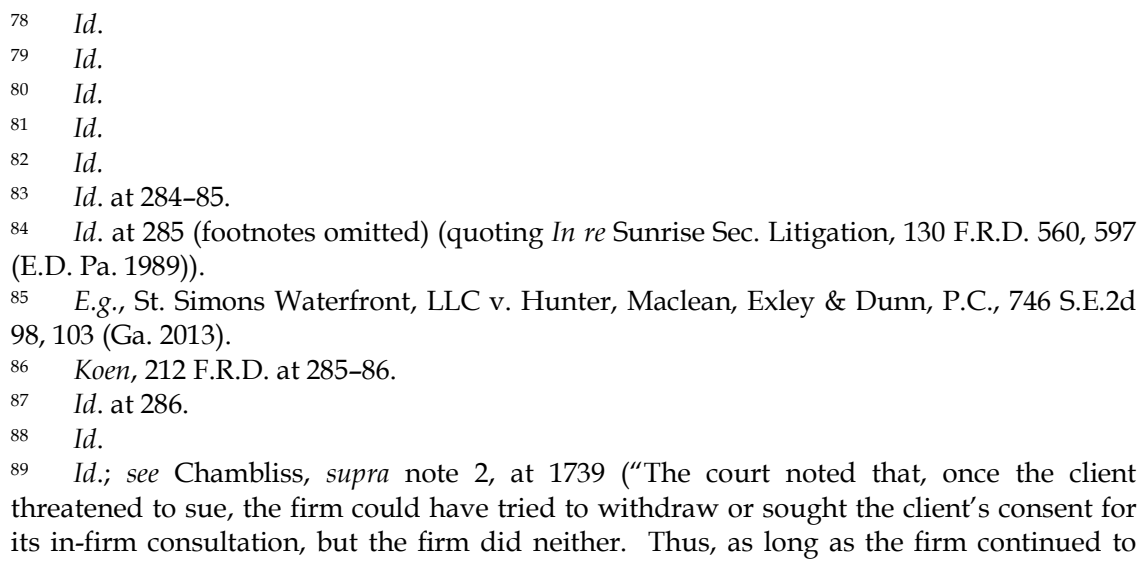




\section{4] Preliminary Thoughts on an Attorney-Client Privilege 725}

A more recent federal decision in this line of authority is the 2008 bankruptcy court decision in In re Sonic Blue Inc. ${ }^{90}$ There the court affirmed the majority Sunrise view with a rhetorical flourish:

[W] hen a law firm chooses to represent itself, it runs the risk that the representation may create an impermissible conflict of interest with one of more of its current clients. In light of these ethical concerns, the courts that have considered the issue have resoundingly found that, where conflicting duties exist, the law firm's right to claim privilege must give way to the interest in protecting current clients who may be harmed by the conflict.... As a result, a law firm cannot assert the attorney-client privilege against a current outside client when the communications that it seeks to protect arise out of self-representation that creates an impermissible conflicting relationship with that outside client. ${ }^{91}$

\section{B. The Growing Minority View}

Although the Sonic Blue court declared in 2008 that "the courts that have considered the issue have resoundingly" affirmed the majority view, ${ }^{92}$ even at that time the assertion was an overstatement. There was contrary federal authority then, ${ }^{93}$ and in 2013 two state supreme courts opted to embrace the minority view. ${ }^{94}$

\section{Federal Authority}

The leading federal authority is the 1996 decision by the Court of Appeals for the Ninth Circuit in United States v. Rowe. ${ }^{95}$ Rowe, a named senior partner at a San Diego law firm, began to suspect that one of its attorneys had mishandled client funds. ${ }^{96}$ He then tasked two young associates to investigate the suspected misconduct. ${ }^{97}$ Rowe exchanged

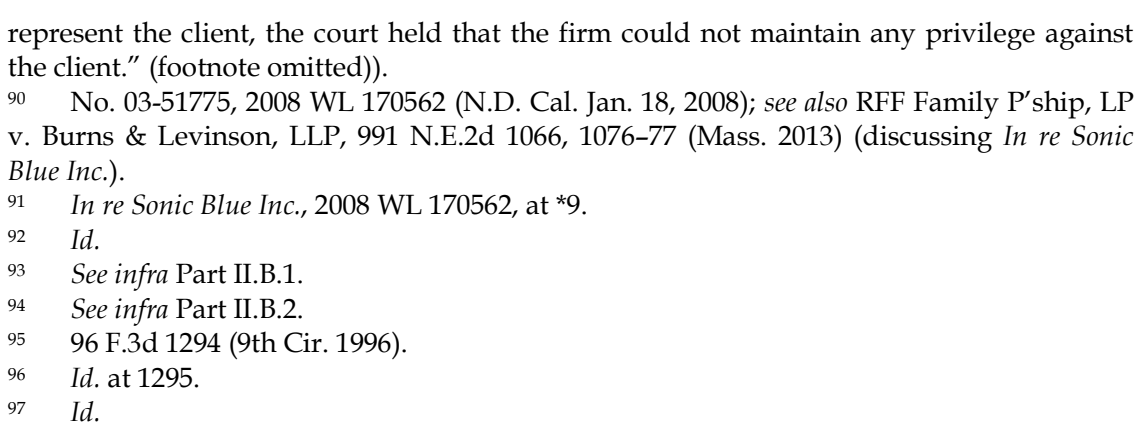


oral communications with the associates about the investigation. ${ }^{98} \mathrm{~A}$ grand jury later undertook an investigation into the misconduct and subpoenaed the associates. ${ }^{99}$ In response, the associates asserted the firm's attorney-client privilege. 100

The district court rejected the associates' claim. ${ }^{101}$ The judge expressed unease about her ruling. ${ }^{102}$ Nevertheless, she ordered the associates to testify:

According to the judge, who had spoken to the associates in camera, "Basically, they were trusted young associates [who] were asked to do some leg work and come up with information.... [T]hey were...helping out." The judge noted that the associates were never told they were working as the firm's attorneys; that they didn't bill the firm or record hours expended on the firm's behalf; and that, because they were far less experienced than Rowe, "[t]hey were certainly taking direction from him."103

Rowe and the firm appealed from the district court order. ${ }^{104}$

On appeal, the Ninth Circuit reversed.105 At the outset of his analysis, Judge Kozinski rejected two distinctions proposed by the United States. ${ }^{106}$ First, the court held that a firm may invoke the attorney-client privilege whether it consults in-house or an outside firm. ${ }^{107}$ Next, relying on the U.S. Supreme Court's decision in Upjohn Co. v. United States, 108 the court brushed aside the government's contention that the lawyer's conduct of a factual investigation does not constitute the rendition of "professional legal services."109

Having repudiated those proposed distinctions, Judge Kozinski found that Rowe and the associates had made out a plausible case that the privilege attached. ${ }^{110}$ Although they were in-house counsel, the

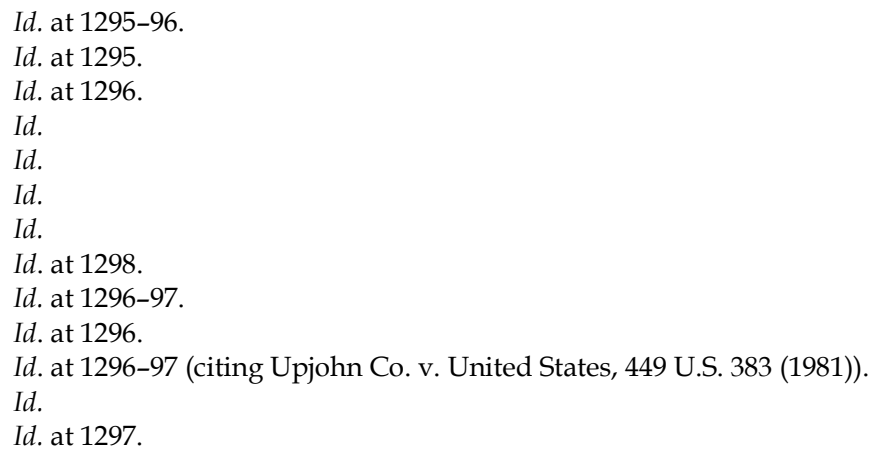




\section{4] Preliminary Thoughts on an Attorney-Client Privilege 727}

associates could qualify as counsel for the firm as a client. ${ }^{111}$ The court conceded that the retention of outside counsel might make it easier for a firm to show that it anticipated litigation; but on the facts in Rowe, "it [was] clear that litigation was anticipated."112 Thus, there was a sufficient inference that the firm had initially sought counsel, that is, the associates, for legal advice. ${ }^{113}$ Further, since Rowe had asked the associates to "sift[] through the facts with an eye to the legally relevant,"' the associates were acting in their capacity as attorneys for the firm during their subsequent investigation. ${ }^{114}$ The Ninth Circuit remanded to the district court for further factual findings rather than finally upholding the privilege claim. ${ }^{115}$ However, the court made it clear that at least in certain circumstances, a firm may assert the privilege to protect intra-firm communications about the potential malpractice claim of a person who was an outside client of the firm at the very time of the communications. ${ }^{116}$

While the Rowe decision antedated Sonic Blue, three years after Sonic Blue another federal court departed from the majority view. In 2011, a federal District Court in Ohio handed down its decision in TattleTale Alarm Systems, Inc. v. Calfee, Halter \& Griswold, LLP.117 The court argued that the majority view has undesirable consequences. ${ }^{118}$ According to the court, the majority view creates a significant disincentive for firm members to consult with more experienced in-house counsel about "rectif[ying] [an error] before the client is irreparably damaged. If such lawyers believe that these communications will eventually be revealed to the client in the context of a legal malpractice case, they will be much less likely to seek prompt advice from members of the same firm."119 In the court's view, in many if not most cases, immediate consultation with experienced in-house counsel is likely to benefit the outside client. ${ }^{120}$ Especially when the firm has designated in-house counsel for these

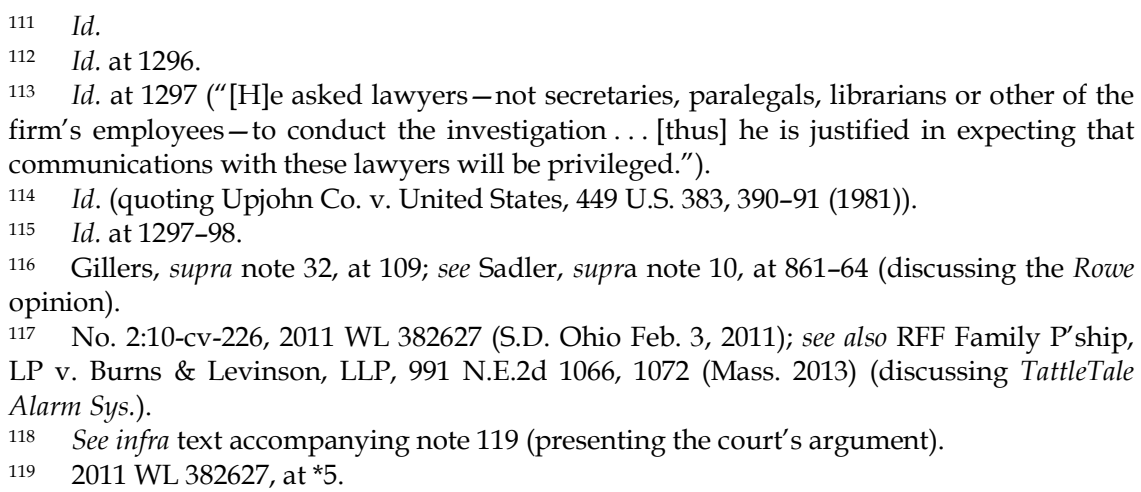


Valparaiso University Law Review, Vol. 48, No. 3 [2015], Art. 8

purposes, the firm's lawyers "should be encouraged to seek advice promptly." 121 The veteran in-house counsel's advice may enable the firm members representing the outside client to moot the malpractice issue by devising a better strategy to prevail for the client in the litigation or transaction. The court implicitly criticized the Bank Brussels opinion, stating that if the firm had to withdraw and seek its own outside counsel, it may be too late to protect the [outside] client from damage.122 The upshot is that as of 2011, there was a sharp split of authority over this issue among the federal courts.

\section{State Authority}

Two 2013 decisions - rendered within a day of each other - added to the momentum toward the minority view. On July 10, 2013, the Massachusetts Supreme Judicial Court handed down its decision in RFF Partnership, LP v. Burns \& Levinson, LLP. ${ }^{123}$ RFF contemplated making a loan secured by what RFF thought would be a first mortgage on certain real property. ${ }^{124}$ RFF hired the firm to investigate the property to ensure that RFF could foreclose on the property if the borrower defaulted. ${ }^{125}$ When the borrower defaulted, RFF sued to foreclose; but, its foreclosure action was enjoined when the assignee of another mortgage on the same property claimed that its mortgage was superior to RFF's.126 While the firm was still representing RFF and seeking to obtain judicial authorization of the foreclosure, RFF hired another law firm, Prince Lobel Tye LLP. ${ }^{127}$ Prince sent the firm a notice that RFF considered the firm guilty of malpractice on the ground that the firm had failed to discover the existing, prior mortgage. ${ }^{128}$ At that point, the firm's attorneys representing RFF consulted with Rosenblatt, a firm partner who had been designated to respond to ethical and risk management issues. ${ }^{129}$ RFF later sued the firm for malpractice. ${ }^{130}$

121 Id. It is true that, in Rowe, the in-house counsel were relatively inexperienced associates. See supra text accompanying note 97 (characterizing the in-house counsel as young associates). However, firms' liability insurers are now pressuring them to appoint experienced counsel to advise junior firm members on matters of legal ethics and risk management, including malpractice claims. See Chambliss, supra note 2, at 1721-22 (explaining that using in-house counsel promotes better risk management and lowers the cost of liability insurance).

122 TattleTale Alarm Sys., 2011 WL 382627, at *5.

123991 N.E.2d 1066 (Mass. 2013).

$124 \quad I d$. at 1068.

$125 \quad I d$.

$126 \quad I d$.

$127 \quad I d$.

$128 \quad I d$.

129 Id. at 1068-69. 


\section{4] Preliminary Thoughts on an Attorney-Client Privilege 729}

When RFF noticed the deposition of the firm attorneys who had represented RFF, the firm sought a protective order. ${ }^{131}$ The firm contended that its attorney-client privilege protected any communications between Rosenblatt and the firm attorneys representing RFF about RFF's potential malpractice claim. ${ }^{132}$ When the trial judge entered the protective order, RFF appealed to the intermediate appellate court. ${ }^{133}$ Since the Supreme Judicial Court believed that the case posed an important issue, by its own motion the court transferred the case to its docket. ${ }^{134}$

On appeal, RFF essentially asked the court to adopt the position endorsed by Koen. ${ }^{135}$ As the Supreme Judicial Court stated:

RFF argues that when an attorney in a law firm seeks legal advice from in-house counsel regarding how the attorney or the firm should respond to a claim or threatened claim of malpractice brought by a current client, these communications are not protected from disclosure to the client unless the law firm, before seeking the advice, has either withdrawn from the representation or fully disclosed to the client that the law firm and client have a conflict of interest and obtained the client's informed consent for the law firm to seek legal advice. ${ }^{136}$

After stating RFF's argument, the court proceeded to reject the argument based on policy and precedent. As a matter of policy, the court agreed with TattleTale that the minority view encourages firm members to seek advice from more experienced firm members about potential malpractice claims and encouraging such conduct is in outside clients' interest. ${ }^{137}$ The court drew upon the assertion in TattleTale that firm members who fear they may have harmed an outside client's interest ought to consult senior firm members who "may be better schooled in ethical rules, and will almost certainly be better capable of dispassionate analysis of the problem at hand." 138 Like the TattleTale

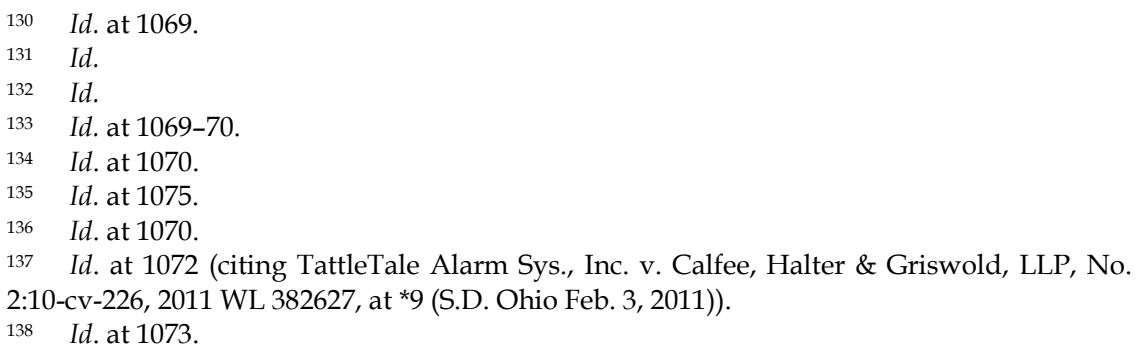


court, the Supreme Judicial Court doubted that firm members would routinely consult senior firm counsel for this purpose if the members realized that "the consultation may not remain private." 139

The court then undertook an analysis of the precedent governing the fiduciary exception to the attorney-client privilege. The court stated that, in the typical situation in which a trustee uses trust funds to pay for an attorney's advice about trust management, "'the beneficiaries [are] the "real clients,"'" and the trustee therefore may not invoke the privilege to prevent the beneficiaries from discovering the contents of the communications between the trustee and the attorney. ${ }^{140}$ The court noted that in 2011 in United States v. Jicarilla Apache Nation, ${ }^{141}$ the U.S. Supreme Court indicated that the trustee cannot invoke the privilege against the beneficiary "when a trustee obtained legal advice to guide the administration of the trust, and not for the trustee's own defense in litigation." 142

However, the Supreme Judicial Court distinguished the atypical case where after a credible threat of litigation between the trustee and beneficiaries has arisen, the trustee seeks legal advice to prepare a defense and pays the lawyer.143 Although a person may have freely agreed to serve as a trustee, he or she "is not completely debilitated" from taking steps "'to defend" himself or herself. ${ }^{144}$ A person does not render himself or herself defenseless by agreeing to become a trustee. The court noted that like a trustee, a lawyer has a right to self-defense. ${ }^{145}$ Indeed, A.B.A. Model Rule 1.6 even permits the lawyer to disclose the client's otherwise privileged communications when necessary to establish the lawyer's defense. ${ }^{146}$

In its next breath, though, the court imposed limitations on the scope of the firm's privilege for in-house consultations. Specifically, the court prescribed "four conditions": (1) the law firm must formally or informally designate the attorney or attorneys within the firm who will "represent the firm in matters as in-house or ethics counsel;" (2) the attorney representing the firm must not have performed any work on the outside client's case or a substantially related matter; (3) the attorney's

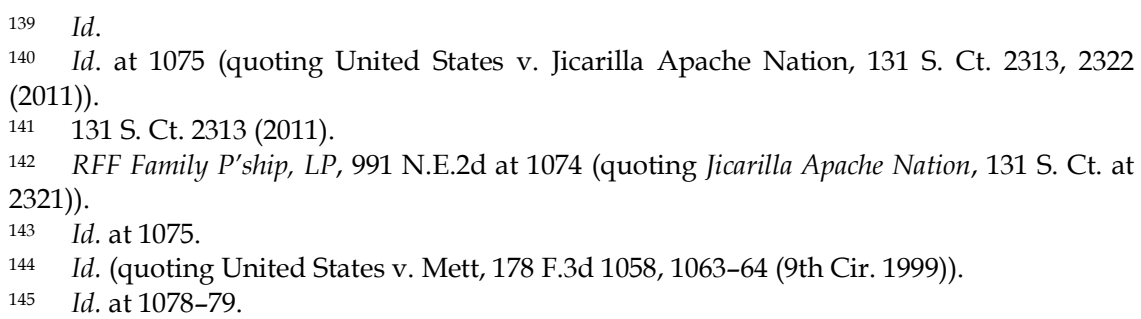




\section{4] Preliminary Thoughts on an Attorney-Client Privilege 731}

time investigating the potential claim against the firm must be billed to the firm rather than the outside client; and (4) the communications between the attorneys representing the outside client and the in-house counsel must be made in confidence and kept confidential. ${ }^{147}$

The very next day, July 11, 2013, the Georgia Supreme Court issued its opinion in St. Simons Waterfront, LLC v. Hunter, Maclean, Exley $\mathcal{E}$ Dunn, P.C. ${ }^{148}$ Like the RFF case, St. Simons adopts the minority view. ${ }^{149}$ St. Simon Waterfront ("SSW") was interested in developing a commercial real estate venture. ${ }^{150}$ SSW hired the firm to perform the legal work related to the venture, including drafting the standard form purchase contract. ${ }^{151}$ However, after a number of prospective buyers had signed the contract, they notified SSW that they intended to rescind because of several "alleged defects in the purchase contract." 152 In a February 2008 conference call between SSW and the firm, SSW indicated that it blamed the firm for the rescissions and would seek to hold it responsible for any damages. ${ }^{153}$ After the call, the participating firm members contacted Arnold Young, the firm's in-house general counsel. ${ }^{154}$ While the firm continued representing SSW, the firm members representing SSW communicated with Young about SSW'S potential malpractice claim.155 In 2009, SSW sued the firm for malpractice. ${ }^{156}$ In the pretrial discovery phase, SSW attempted to depose firm members concerning the in-house consultations about the malpractice claim and demanded the production of documents reflecting the consultations. ${ }^{157}$ The firm objected on the basis of the attorney-client privilege and filed a privilege log supporting the objection. ${ }^{158}$

The trial judge overruled the objection. ${ }^{159}$ Following the majority view, the judge reasoned that the in-house consultations created a conflict of interest between the outside client's and firm's interests and

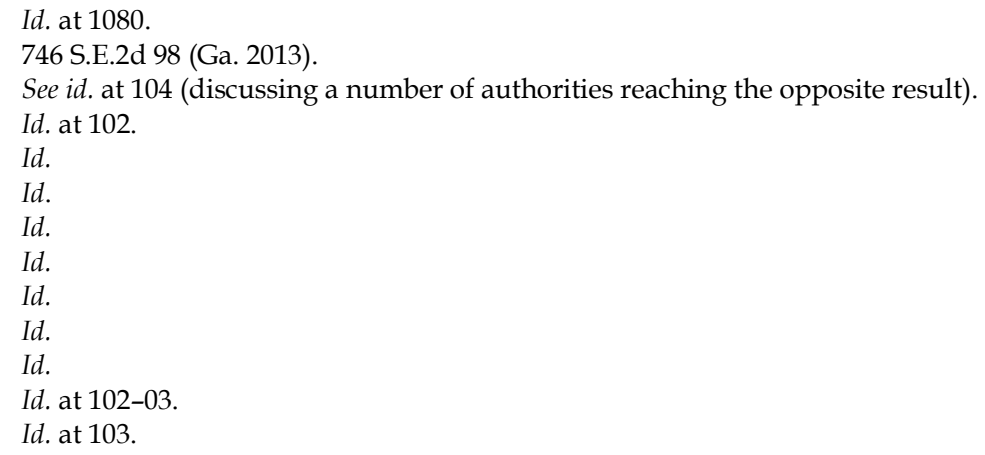


that the conflict "negated" the privilege. ${ }^{160}$ The firm appealed, and the case eventually reached the state supreme court. ${ }^{161}$

After describing the procedural setting and the underlying facts, the court acknowledged that there was a split of authority on the issue; and, in its survey of the case law, the court identified three competing views. ${ }^{162}$ The views span a wide spectrum: (1) one extreme position is that the firm cannot claim a privilege against the outside client "under any circumstances" if the attorney-client relationship with the client existed at the time of the in-house consultations; (2) other courts hold that "the privilege applies only in limited circumstances," which include such procedural safeguards as notifying the outside client of the fact of the ongoing, in-house consultations; and (3) still another view is that "the privilege does apply or that it applies with narrow exceptions."163

Rather than formally adopting any of the competing views, the court announced that "the best course is simply to analyze the privilege issue here as we would in any other lawsuit in which the privilege is asserted."164 Like the RFF court, the court described the steps that the firm should take to establish that the firm itself has become a client entitled to the protection of the privilege. The court indicated the following: The attorney advising the firm members representing the outside client should not participate in the underlying representation; the attorney ought to open a new file separate from the files for the outside client's case; the attorney must bill his or her time to the firm, not the outside client; and the firm should designate the attorney as firm inhouse counsel with some "level of formality." 165 The court stated that the ideal structural arrangement is one in which the designated counsel "holds a full-time position as firm counsel to the exclusion of other work." 166 The court stated that if the firm observed these practices, the firm members could be deemed representatives of the firm as a client consulting the in-house lawyer; the members would not be considered as merely "consulting with a colleague as part of their representation of [an outside] client or discussing general firm business." 167 If the firm follows that practice, the firm would then have an opportunity to make a

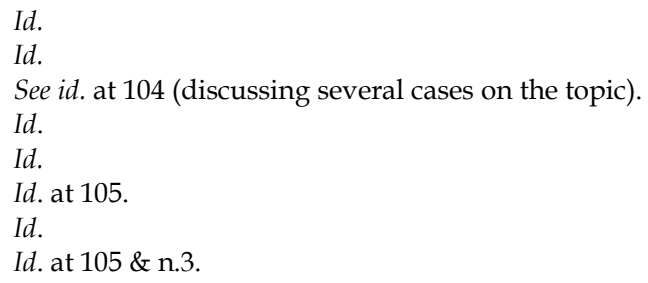


showing that all the normal requirements for the privilege, such as confidentiality, have been satisfied. ${ }^{168}$

In the second half of the opinion, the court grappled with the tension between the privilege and the firm's ethical responsibilities to the outside client. The court conceded that some courts had concluded that those ethical duties trump the firm's entitlement to the attorney-client privilege. ${ }^{169}$ The court referred to the Koen theory that a fiduciary exception precludes the firm from asserting the privilege for communications relating to a potential malpractice claim by a then current client. ${ }^{170}$

However, the court advanced two counter-arguments. The first was that evidentiary and ethical rules can differ. ${ }^{171}$ In the court's words, "this opinion is not intended to resolve the ethical quandary and instead addresses only the evidentiary questions of privilege."172 The court pointed to "our State Bar's admonition that the Rules of Professional Conduct are not intended to affect the law of privilege."173 Assuming that there is a fiduciary exception in legal ethics, the court "decline[d] to adopt the fiduciary exception to the attorney-client privilege in this context." 174 The court's second counter-argument was that the firm is not guilty of any unethical conduct unless the firm endeavors to mislead the outside client about the in-house consultations. ${ }^{175}$ In dictum, the court stated that "to the extent there is an allegation that in-house counsel has been employed by firm attorneys in an effort to defraud rather than merely defend against a client, the privilege" would be unavailable. ${ }^{176}$ There was no such allegation in the Georgia case.

\section{A CRitical EVAluation OF THE THRESHOLd POLICy Question OF WHETHER A FIRM SHOUld EVER ENJOY A PRIVILEGE PROTECTING INTERNAL CONSULTATIONS BETWEEN IN-HOUSE COUNSEL AND THE COUNSEL REPRESENTING A CURRENT CLIENT WHO HAS INDICATED THAT IT MAY SUE THE FIRM FOR MALPRACTICE}

In Part II, this Article demonstrated that the courts are sharply divided over the questions of whether, and in what circumstances, a law

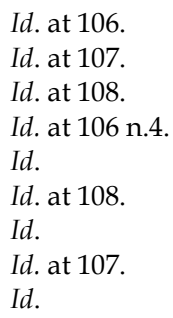


Valparaiso University Law Review, Vol. 48, N0. 3 [2015], Art. 8

firm may invoke the attorney-client privilege to protect internal consultations between an in-house counsel and the firm members representing an outside client when the subject of the consultation is a potential claim by the then current client. ${ }^{177}$ This Part addresses the threshold policy question of whether a firm should ever be able to assert the privilege against such an outside client. First, Part III.A discusses situations where an attorney's duty of confidentiality is excused to obtain legal advice about compliance with the ethical rules, or where the lawyer needs to defend himself against a claim. ${ }^{178}$ Next, Part III.B analyzes the different ethical and policy considerations relevant to the propriety of treating a law firm as its own client when determining whether the firm enjoys a privilege. ${ }^{179}$

\section{A. The Case for Granting the Firm a Privilege}

When an outside client threatens a malpractice suit, the law firm undeniably has substantial interests, both financial and reputational, at stake. If the former client prevails in a malpractice action, the firm could suffer an adverse judgment in the millions. ${ }^{180}$ Even if the former client does not sue, unfavorable publicity for the potential claim can damage the firm's reputation and reduce its future ability to attract clientele.

The rules of legal ethics reflect that these are legitimate interests worthy of legal protection. ${ }^{181}$ In particular, two provisions of A.B.A. Model Rule 1.6 reflect the bar's recognition of the legitimacy of the interests. Rule 1.6 governs the attorney's duty of confidentiality to the client. ${ }^{182}$ Rule 1.6(a) prescribes that the attorney generally has a duty to maintain the confidentiality of information relating to the client's representation. ${ }^{183}$ However, Rule 1.6(b) lists a number of exceptions to the general rule. ${ }^{184}$ Rule 1.6(b)(4) provides that the attorney may disclose otherwise confidential information "to secure legal advice about the

\footnotetext{
177 See supra Part II.

178 See infra Part III.A.

179 See infra Part III.B.

180 See VAIL \& EWINS, supra note 3, at 14 tbl.7A (identifying fifty-two cases between 2007 and 2011 when a client won $\$ 1,000,000$ or more from a malpractice action).

181 See, e.g., RFF Family P'ship, LP v. Burns \& Levinson, LLP, 991 N.E.2d 1066, 1078 (Mass. 2013) (explaining the interests embodied in Rule 1.10); see also Chambliss, supra note 2, at 1753 (referencing Rule 1.6).

182 Model Rules OF PROF'L CONDUCT R. 1.6 (2011); see Charles W. Sorenson, Jr., Are Law Clerks Fair Game? Invading Judicial Confidentiality, 43 VAL. U. L. REV. 1, 39 n.184 (2008) (discussing Rule 1.6).

183 MODEL RUlES OF PROF'L CONDUCT R. 1.6(a) (2011)

184 Id. at R. 1.6(b); Stephen Gillers, Virtual Clients: An Idea in Search of a Theory (with Limits), 42 VAL. U. L. REV. 797, 806 (2008).
} 


\section{4] Preliminary Thoughts on an Attorney-Client Privilege 735}

lawyer's compliance with these Rules."185 Further, Rule 1.6(b)(5) explicitly provides that the attorney may disclose such information "to establish a ... defense on behalf of the lawyer in a controversy between the lawyer and the client."186 Official Comment 11 states that Rule 1.6(b)(5) extends to fee disputes with the client when the lawyer is attempting to protect his or her financial interests. ${ }^{187}$

These provisions implicitly recognize the magnitude of the firm's interests. In the type of dispute that is our principal focus, the question is whether the former outside client can discover the firm's own internal consultations about the malpractice claim. In contrast, Rule 1.6(b) enumerates situations in which the lawyer has the right to disclose the client's own privileged communications over the client's protest. ${ }^{188}$ The outside client has a more intense interest in the privacy of its own communications. If the lawyer's reputational and financial interests are substantial enough to defeat the client's confidentiality expectation in its own communications, there is all the more reason to conclude that those interests warrant extending a privilege to the firm's internal communications in which the outside client did not participate at all.

Similarly situated entities enjoy a privilege to protect their comparable interests. A law firm is a business organization. ${ }^{189}$ It is well settled that business partnerships and associations can qualify as holders of the attorney-client privilege.190 Indeed, one of the leading cases following the majority view, Sunrise, recognized that point of law. ${ }^{191}$ California's statutory provisions are illustrative. California Evidence Code section 951 governing the attorney-client privilege defines "client" as any "person" consulting an attorney for legal advice.192 In turn,

\footnotetext{
185 MOdel RUles of Prof'́ CONDUCT R. 1.6(b)(4) (2011).

186 Id. at R. 1.6(b)(5).

187 Id. at R. 1.6(b)(5) cmt. 11

188 Id. at R. 1.6(b).

189 Sadler, supra note 10 , at 867.

190 See 1 IMWINKELRIED, supra note 9, § 6.5.1, at 557-58 (discussing the attorney-client privilege available to entities such as associations, corporations, and government agencies); Chambliss, supra note 2, at 1728-29 (discussing cases recognizing a privilege for in-house counsel); Gillers, supra note 32, at 107 ("It is settled law that the attorney client privilege protects communications between corporate directors, officers or employees and in-house corporate counsel."); Sadler, supra note 10, at 866 (recognizing that the A.B.A. treats partnerships, corporations, and other legal entities the same under Rule 1.13); see also John Hasnas, Between Scylla and Charybdis: Ethical Dilemmas of Corporate Counsel in the World of the Holder Memorandum, 44 VAL. U. L. REV. 1199, 1210 (2010) (discussing ethical issues regarding the corporate attorney-client privilege).

191 In re Sunrise Sec. Litig., 130 F.R.D. 560, 595 (E.D. Pa. 1989)) (“[A] law firm, like other business or professional association [may] receive the benefit of the attorney client privilege when seeking legal advice from in-house counsel.").

192 CAL. EVID. CODE § 951 (West 2009).
} 
section 175 defines a person as "includ[ing] a natural person, firm, association, organization, partnership, business trust, corporation ... or public entity." 193 Given the breadth of this rule and the substantiality of the firm's legitimate interests, the RFF court found "'no principled reason'" for denying a privilege to the firm for its internal consultations about potential malpractice claims. ${ }^{194}$

\section{B. The Case Against Granting a Privilege}

That, of course, is the key policy issue: Is there a principled distinction between a law firm and a non-legal partnership that does enjoy a privilege? The proponents of the traditional, majority view have urged two bases for recognizing a distinction. The first basis for recognizing a distinction that opponents of the privilege rely on is the conceptual objection of treating a law firm as its own client. ${ }^{195}$ The second basis relied on is the ethical objection of treating a law firm as its own client. ${ }^{196}$

\section{The Conceptual Objection to Treating a Law Firm as Its Own Client}

Several courts following the majority view have professed that they cannot understand how a law firm can at once be the attorney for the outside client as well as its own client. As we saw in Part II.A, the McCormick court asked rhetorically: "If the McCormick firm was the client, who was its lawyer?"197 The Sunrise court voiced the same doubt when it questioned how the firm as lawyer and the firm as client could be represented by attorneys who are members of "one and the same entity." 198

However, this conceptual argument does not establish the logical impossibility of treating some firm members as client (the attorneys representing the outside client) at the same time that another firm member (the in-house counsel) serves as attorney. In rejecting the argument, the Rowe court analogized to the law governing the privilege between corporations and their in-house counsel. ${ }^{199}$ It is true that some

\footnotetext{
CAL. Evid. CoDE $§ 175$ (West 2011).

RFF Family P'ship, LP v. Burns \& Levinson, LLP, 991 N.E.2d 1066, 1072 (Mass. 2013) (quoting Hertzog, Calamari \& Gleason v. Prudential Ins. Co. of Am., 850 F.Supp. 255, 255 (S.D.N.Y 1994)).

195 See infra Part III.B.1.

196 See infra Part III.B.2.

197 Gillers, supra note 32, at 110.

198 In re Sunrise Sec. Litig., 130 F.R.D. 560, 572 (E.D. Pa. 1989); Chambliss, supra note 2, at 1728 (quoting In re Sunrise, 130 F.R.D. at 572).

199 United States v. Rowe, 96 F.3d 1294, 1296 (9th Cir. 1996); Sadler, supra note 10, at 860.
} 


\section{4] Preliminary Thoughts on an Attorney-Client Privilege 737}

European countries do not recognize a legal privilege between a corporate entity and its in-house counsel. ${ }^{200}$ However, in the United States the law is to the contrary. ${ }^{201}$ Under domestic American law, a corporate client can have an attorney-client relationship with one of its own employees, that is, its paid in-house counsel.202 In 1915, the U.S. Supreme Court ruled that an in-house counsel can qualify as the attorney for the purposes of creating an attorney-client relationship with his or her corporate employer. 203 "At the present time, all jurisdictions within the United States, both state and federal, recognize the attorney-client privilege for in-house counsel." 204

In the situation described in the preceding paragraph, the corporate entity constitutes the client while an employee of the entity, the in-house counsel, functions as attorney. One natural person employee, the inhouse counsel, provides legal services to other natural person corporate employees, who personify the entity client. Similarly, although a law firm usually serves as attorney for outside clients, the firm can don the hat of client and enter into a privileged attorney-client relationship with one of its own members, the designated firm counsel. Here too one natural person member, the designated counsel, furnishes legal advice to other natural person members, the firm attorneys representing the outside client. The existence of the artificial entity should not obscure the human reality that different natural persons are performing the attorney and client roles. In a very real sense, there is a division of labor. Hence, logic does not dictate denying a law firm a privilege for its internal consultations between in-house counsel and the firm members representing an outside client. If the privilege is to be denied, it must be done on more substantial policy grounds.

\section{The Ethical Objection to Treating a Law Firm as Its Own Client}

The second basis relied on by opponents of treating law firms as their own client and granting them privilege is ethical. The proponent's arguments and critiques of their arguments will be discussed in the following paragraphs. ${ }^{205}$

\footnotetext{
200 See 2 IMWINKELRIED, supra note 71, §12.2, at 1658 n.1 (discussing the approach to inhouse counsel and attorney-client privilege used by several European countries). 
Valparaiso University Law Review, Vol. 48, N0. 3 [2015], Art. 8

738

a. The Proponents' Arguments

The proponents of the majority view contend that there are such grounds, based on legal ethics. They advance a formal argument as well as a more fundamental argument based on the policies inspiring legal ethical rules.

The formal argument is that treating the firm as its own client violates the A.B.A. Model Rules of Professional Conduct by creating an unethical conflict of interest for the in-house counsel advising the firm members representing the outside client. A.B.A. Model Rule 1.7(a)(1) declares that an attorney may not "concurrent[ly]" represent two clients when "the representation of one client will be directly adverse to another client." 206 Model Rule 1.10 announces a general rule that when one firm member is disqualified from representing a client, the other members of the same firm are vicariously disqualified from doing so. ${ }^{207}$ The proponents of the majority view point to those two rules and argue along these lines: The firm members representing the outside client certainly cannot directly oppose the client's interests - as the outside client's counsel, they are personally disqualified from doing so; ordinarily, a personal conflict of one firm member is automatically imputed to other firm members; if the personal conflict of the members representing the outside client is vicariously imputed to the firm's inhouse counsel, that counsel must be deemed to be simultaneously representing and opposing the outside client; and the latter, in-house firm counsel therefore has a disqualifying, actual conflict of interest. 208 The Bank Brussels court encapsulated this line of argument when it asserted that "a conflict as to one attorney at a firm [the member representing the outside client] is a conflict as to all [including the inhouse counsel purporting to represent the firm itself]." 209

\footnotetext{
206 MOdEL RULES OF PROF'L CONDUCT R. 1.7(a)(1) (2013).

207 Id. at R. 1.10.

208 See In re SonicBlue, Inc., No. 03-51775, 2008 WL 170562, at *12 (N.D. Cal. Bankr. Ct. Jan. 18, 2008); RFF Family P'ship, LP v. Burns \& Levinson, LLP, 991 N.E.2d 1066, 1077-78 (Mass 2013) (discussing and rejecting RFF's argument that Rosenblatt should have been simultaneously representing the firm itself and "imputed[ly] represent[ing] RFF" (citing In re Sunrise Sec. Litig. 130 F.R.D. 560, 597-98 (E.D. Pa. 1989)); see also St. Simons Waterfront, LLC v. Hunter, Maclean, Exley \& Dunn, P.C., 746 S.E.2d 98, 105 (Ga. 2013) (“This automatic imputation of one attorney's conflicts to all other attorneys in the firm is the basis on which some courts have refused to recognize any privilege for intra-firm communications." (citing Bank Brussels Lambert v. Credit Lyonnais (Suisse), S.A., 220 F. Supp. 2d 283, 288 (S.D.N.Y. 2002)); Chambliss, supra note 2, at 1724 (explaining the denial of privilege based on the arguments for conflict of interest "by imputing the firm's duty to the client to inhouse counsel as a member of the firm").

209 Bank Brussels Lambert, 220 F. Supp. 2d at 288.
} 


\section{4] Preliminary Thoughts on an Attorney-Client Privilege 739}

At a more fundamental level, the proponents of the traditional view contend that the conflict rules are intended to enforce the firm's duty of loyalty to the outside client. Koen is an eloquent statement of the contention. After discussing the formal conflict rules set out in Pennsylvania's version of Model Rule 1.7, the court cites Sunrise and rests its decision squarely on the lawyer's fiduciary duties to the client. ${ }^{210}$ Faced with a policy choice between enforcing those duties and protecting the firm's interests, the court stated that those fiduciary duties are "paramount." 211

\section{b. The Critique of the Proponents' Arguments}

Although the proponents' arguments seem plausible, there are persuasive responses to the proponent's formal argument as well as their policy argument. Professor Chambliss has presented a critique of the formal argument. ${ }^{212}$ In its 2013 decision, the Massachusetts Supreme Judicial Court endorsed Professor Chambliss's criticism of the traditionalists' construction of the Model Rules. ${ }^{213}$ Her analysis convinced the court that in the typical case, it does not significantly serve either the firm's duty of loyalty or the outside client's confidentiality interests to "apply[] the [formal] rule of [vicarious] imputation to the representation of a law firm by its in-house counsel." 214

She begins her critique by noting that the commentary and judicial gloss on the conflict rules demonstrate that those rules are intended primarily as means of enforcing the attorney's duties of confidentiality and loyalty to the client. ${ }^{215}$ She explains that neither ethical duty requires the vicarious imputation of the conflict of the firm members representing the outside client to the firm's in-house counsel.216 Her analysis of the confidentiality rationale for the conflict rules is trenchant. As she observes, the foremost rationale for the confidentiality duty is to prevent the attorney from disclosing the client's confidential information to third parties. ${ }^{217}$ In her mind, it makes little sense to treat confidentiality as a rationale for the automatic imputation, since

\footnotetext{
210 Koen Book Distribs. v. Powell, Trachtman, Logan, Carrle, Bowman \& Lombardo, P.C., 212 F.R.D. 283, 285-86 (E.D. Pa. 2002).

211 Id. at 286

212 See Chambliss, supra note 2, at 1724 (arguing for broad protection of communication with a law firm's in-house counsel).

213 RFF Family P'ship, 991 N.E.2d at 1071-72.

$214 \quad$ Id. at 1078.

215 Chambliss, supra note 2 , at $1747-48$.

216 Id.

$217 \quad I d$
} 
affiliated lawyers in the same firm already have access to the firm's files containing client confidences. ${ }^{218}$

She also addresses the duty of loyalty. She notes that the Model Rules recognize the firm's right of self-defense-a right that would even permit the firm to disclose the outside client's own privileged communications in which the outside client obviously has an intense privacy interest. ${ }^{219}$ As she writes, "the firm's duty of loyalty to the client does not prevent the firm from attempting to defend against client claims. This effort to defend is no more 'disloyal' when it involves inside rather than outside counsel." 220 Although there is merit to this part of her critique, it is not wholly satisfying. While the firm has a right "to defend [itself] against client claims," 221 she glosses over the difference between the firm's well-settled right to defend itself after the client terminates its services and the firm's more debatable entitlement to take defensive measures while it still represents the client. Intuitively, there would appear to be a distinction. To come to grips with that distinction, we must turn to the traditionalists' more fundamental argument based on the firm's fiduciary duty of loyalty to a current client.

The traditionalists' reliance on the attorney's fiduciary duty is misplaced. The traditionalists are correct in pointing out that when in a classic trust relationship, the trustee spends trust funds to hire an attorney to advise the trustee on the regular management of the corpus, the courts treat the cestui que trust (the beneficiary) as the real client and prevent the trustee from asserting the attorney-client privilege against the beneficiary. In 2011 in the Jicarilla Apache Nation case, the U.S. Supreme Court recognized that generalization but noted that even today "[s]ome state courts have altogether rejected the notion that the attorneyclient privilege is subject to a fiduciary exception." 222

But even positing the existence of the exception, the traditionalists' analysis of the case law is incomplete. The generalization they rely on is merely the starting point in the analysis. As the Jicarilla Court noted, the origin of the fiduciary exception is traceable to conventional trust cases.223 However, many of the modern cases are Employee Retirement Income Security Act of 1974 (ERISA) lawsuits involving the administration of pension trust funds. ${ }^{224}$ There is a wealth of ERISA case

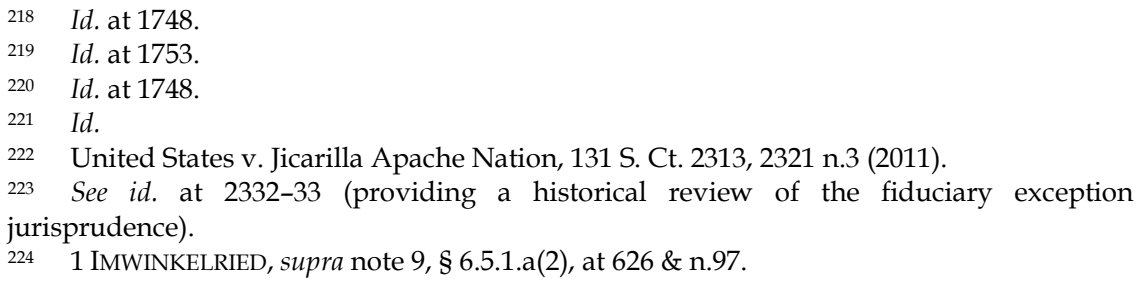


law analyzing the question of when the pension fund trustee may invoke the attorney-client privilege against the beneficiaries. ${ }^{225}$ The cases apply the fiduciary exception to the trustee's communications with the trust counsel at the inception of the trust when there is a cooperative relationship between the trustee and the pensioner beneficiaries.226 However, the cases recognize that at some point, it may become reasonably clear to the trustee that its interests have diverged from those of the beneficiary.227 For example, the trustee might conclude that the beneficiary contemplates suing the trustee for mismanagement. Under the modern case law, when the trustee forms that belief, the trustee has a perfect right to hire counsel at the trustee's own expense to prepare for any possible litigation; and the attorney-client privilege will shield the communications between the trustee and its counsel from the beneficiaries.228 Significantly, the privilege applies even though the trustee consults its counsel while the trustee-beneficiary relationship continues.

The parallel to the intra-firm privilege issue is evident. When in one way or another the outside client indicates that he or she may sue the firm for malpractice, the interests of the outside client and the firm have diverged. At that point, under the modern fiduciary exception case law the firm may seek counsel to prepare for the outside client's possible lawsuit against the firm. ${ }^{229}$ The Jicarilla case stated that an important clue to the client's identity is the payor of the attorney's fee.230 In Justice Alito's words, "[c]ourts look to the source of funds as a 'strong indicator of precisely who the real clients were' and a 'significant factor' in determining who ought to have access to the legal advice." 231 If the law firm instructs its in-house counsel to bill his or her time investigating the malpractice claim to the firm rather than the client, the instruction is important evidence that the firm is the real client. 232 In these circumstances, consistently with the ERISA case law, the firm may claim the privilege even against the person or company who was the firm's

\footnotetext{
225 See id. § 6.5.1.a(2), at 626 n.97 (citing a plethora of cases on this issue).

Id.

See generally, Kirsten H. Jensen, The Fiduciary Exception to the Attorney-Client Privilege, PRAC. LAW., Oct. 2007, at 31, 32-34, 40-42 (Oct. 2007) (discussing the fiduciary exception and divergent interests).

2281 IMWINKELRIED, supra note 9, § 6.5.1.a(2), at 625-26.

229 See supra Part II.B. (providing case law on the growing minority view recognizing an attorney-client privilege for in-house counsel).

230 United States v. Jicarilla Apache Nation, 131 S. Ct. 2313, 2330 (2011).

231 Id. at 2326 (quoting Riggs Nat'l Bank of Washington, D.C. v. Zimmer, 355 A.2d 709,

712 (Del. Ch. 1976)).

232 RFF Family P'ship, LP v. Burns \& Levinson, LLP, 991 N.E.2d 1066, 1075 (Mass. 2013).
} 
Valparaiso University Law Review, Vol. 48, N0. 3 [2015], Art. 8

outside client at the time of the internal consultations. ${ }^{233}$ The upshot is that the firm has legitimate, substantial interests warranting the protection of the attorney-client privilege, and none of the traditionalists' counter-arguments can withstand close scrutiny.

\section{A CRITICAl EVAluATION OF THE QUESTION OF THE SCOPE OF THE INTRA-FIRM PRIVILEGE: WHAT CONDITIONS SHOULD THE COURT IMPOSE TO LIMIT THE EXTENT OF THE PRIVILEGE?}

Part III concluded that at least in some circumstances, a law firm should be able to assert the attorney-client privilege for communications between the firm's in-house counsel and the firm members representing an outside client about a potential malpractice claim even when the party later seeking discovery is the former outside client.234 However, even assuming that an intra-firm privilege of some sort should exist, the question remains: What should be its extent or scope?235 In what specific circumstances should the courts recognize the privilege?236

First, this section argues which internal steps a firm should take to establish its identity as the client of its in-house counsel.237 Second, it explains what the firm's external relations with the outside client should entail. 238

A. The Internal Steps the Firm Should Take to Establish Its Identity as the Client of Its In-House Counsel

In the 2013 Georgia and Massachusetts decisions, the state supreme courts underscored that the firm ought to implement procedures to ensure that both the firm's in-house counsel and the firm members representing the outside client understand that the client of the in-house counsel is the firm itself. ${ }^{239}$ The firm must put in place appropriate structural arrangements. ${ }^{240}$ Admittedly, both decisions are so recent that

\footnotetext{
233 E.g., id.

234 See sufra Part III.

235 See Chambliss, supra note 2, at 1748 (suggesting that the scope of the in-firm privilege "vis-à-vis current clients should turn on the facts of the representation at issue"); Sadler, supra note 10, at 873 ("Rowe leaves unanswered the question as to the extent of the privilege when the communication directly related to the client who is seeking discovery.").

236 See Sadler, supra note 10, at 867-68 (expounding on this question).

237 See infra Part IV.A.

238 See infra Part IV.B.

239 St. Simons Waterfront, LLC v. Hunter, Maclean, Exley \& Dunn, P.C., 746 S.E.2d 98, 104-05 (Ga. 2013); RFF Family P'ship, LP v. Burns \& Levinson, LLP, 991 N.E.2d 1066, 107172 (Mass. 2013).

240 Chambliss, supra note 2, at 1745-50 (discussing courts' treatment of this issue and proposing a structural approach).
} 
it would be premature to predict the final form of the required procedures and structures. However, both courts expressed relatively strong preferences on four structural arrangements.

First, the firm should formally or informally designate the in-house counsel as the attorney whom firm members are to consult about ethical problems such as potential malpractice claims by current clients. ${ }^{241}$ It would be ideal if the firm formalized the counsel's role by (1) selecting an attorney to serve in the role in a permanent, full-time basis with no outside practice; and (2) giving the attorney a title signaling his or her special role. ${ }^{242}$ The next best arrangement would be to designate an attorney who serves as firm counsel on a part-time but ongoing basis. ${ }^{243}$ However, a court might be willing to extend the privilege even when the attorney was designated on an ad hoc basis, ${ }^{244}$ as the San Diego firm appointed the two associates in United States $v$. Rowe. ${ }^{245}$ In Rowe, Rowe appointed the two associates to investigate the alleged mishandling of client funds even though they had never before functioned as counsel for the firm. ${ }^{246}$ Nevertheless, Judge Kozinski characterized them as "effectively ... in-house counsel." 247 However, as a practical matter a court is much more likely to find an affirmative understanding that the in-house attorney's client was the firm itself when the firm goes to the trouble to select experienced counsel and institutionalize a more formal arrangement. ${ }^{248}$

The second procedure is negative in nature. Before the time when the firm formed the belief that the outside client might sue for malpractice, the attorney in question should not have participated in the client's representation; ${ }^{249}$ and once the firm forms that belief, the attorney

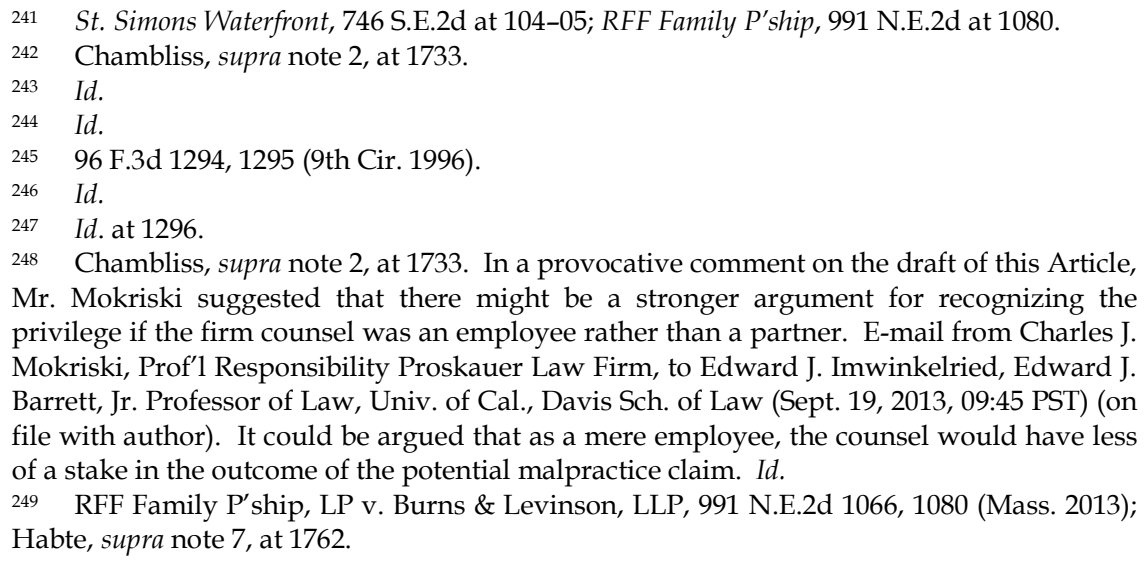
Mr. Mokriski suggested that there might be a stronger argument for recognizing the privilege if the firm counsel was an employee rather than a partner. E-mail from Charles J. Mokriski, Prof'l Responsibility Proskauer Law Firm, to Edward J. Imwinkelried, Edward J. Barrett, Jr. Professor of Law, Univ. of Cal., Davis Sch. of Law (Sept. 19, 2013, 09:45 PST) (on file with author). It could be argued that as a mere employee, the counsel would have less of a stake in the outcome of the potential malpractice claim. Id.

249 RFF Family P'ship, LP v. Burns \& Levinson, LLP, 991 N.E.2d 1066, 1080 (Mass. 2013); Habte, supra note 7 , at 1762. 
Valparaiso University Law Review, Vol. 48, N0. 3 [2015], Art. 8

certainly ought not to participate in the representation. ${ }^{250}$ The in-house attorney is undertaking to advise the firm-a representation distinct from the other attorneys' representation of the outside client.251

The third and fourth procedural requirements flow from the prior two. The third is that the in-house counsel should open a new file separate from the file for the outside client. ${ }^{252}$ After opening the new file, the in-house counsel should ensure that the documents for the two distinct representations are not commingled. ${ }^{253}$ In the words of the Georgia Supreme Court, this records practice "helps distinguish the firm as the in-house counsel's client and the claim against the firm as a matter independent of the underlying representation." 254

The fourth and final requirement is a billing practice. Rather than billing the client for the in-house counsel's services, ${ }^{255}$ the firm ought to assign a separate billing number; ${ }^{256}$ and all the charges allocable to that number must be billed to the firm itself. ${ }^{257}$ As previously stated, in its 2011 Jicarilla Apache Nation decision, the U.S. Supreme Court observed that the identity of the payor is "a 'strong indicator of precisely who the real clients'" are. ${ }^{258}$

If the firm adopts these four internal practices and both the in-house counsel and the attorneys representing the outside client are aware of these practices, there is a strong case that the firm itself has established its status as the in-house counsel's client. To be sure, subsidiary issues will arise as the courts refine the understanding of these practices and shape their final form. ${ }^{259}$ However, the major remaining policy question

250 Chambliss, supra note 2, at 1732. As a corollary to the in-house counsel's noninvolvement in the representation of the outside client, the counsel should not share in any fee paid by the outside client. $I d$. at 1745 .

251 St. Simons Waterfront, LLC v. Hunter, Maclean, Exley \& Dunn, P.C., 746 S.E.2d 98, 104-05 (Ga. 2013). In another comment on the draft of this Article, Mr. Mokriski asked: "[S]hould the lawyers involved as targets of potential malpractice claims, who are continuing to represent the client ... be privy to the advice of the firm counsel, or should they be screened from it[?]" E-mail from Charles J. Mokriski, supra note 248.

252 Gillers, supra note 32, at 109; Habte, supra note 7, at 1762.

253 St. Simons Waterfront., 746 S.E.2d at 105.

$254 \quad I d$.

255 RFF Family P'ship, LP v. Burns \& Levinson, LLP, 991 N.E.2d 1066, 1080 (Mass. 2013).

256 Chambliss, supra note 2, at 1749; Gillers, supra note 32, at 111.

257 RFF Family P'ship, 991 N.E.2d at 1080 ("Because the law firm is the client . . . , their cost must be borne by the law firm.").

258 United States v. Jicarilla Apache Nation, 131 S. Ct. 2313, 2326 (2011) (quoting Riggs Nat'l Bank of Washington, D.C. v. Zimmer, 355 A.2d 709, 712 (Del. Ch. 1976)); see E-mail from Charles J. Mokriski, supra note 248 (questioning the realism of the condition, since "[c]ompensation setting for partners in law firms is so complex and arbitrary that it is difficult to trace client fee revenues to any member of the firm.").

259 See generally E-mail from Charles J. Mokriski, supra note 248 (identifying several of those questions). 
becomes whether, in its external relations with the outside client, the firm has conducted itself in a manner that justifies requiring the outside client to respect the firm's internal confidential consultations. Part IV.B turns to that question. 260

\section{B. The Firm's External Relations with the Outside Client}

Just as there is general consensus on the internal procedures that the firm should follow to claim an intra-firm privilege, there is agreement on some of the things the firm must do to fulfill its professional responsibilities to the outside client. To begin, if the client does not realize that an event has occurred that may give rise to a malpractice claim against the firm, the firm must notify the client of the existence of the potential claim. ${ }^{261}$ Of course, when the firm makes this disclosure to the outside client, the firm should also explain that the client has the right to consult independent counsel about the validity and pursuit of the potential claim. ${ }^{262}$

However, there the consensus ends. At this point, the troublesome question arises: Before consulting in-house counsel about the claims (and becoming entitled to invoke the attorney-client privilege), must the firm seek and obtain the outside client's consent to the firm's internal consultations about a defense against the potential claim? That question is reducible to two sub-issues. ${ }^{263}$

1. If It Becomes Clear that the Outside Client May Sue the Firm for Malpractice, Does that Development Ipso Facto Create an Actual Conflict of Interest Requiring the Firm to Obtain the Client's Consent Before Conducting Internal Consultations Between the Attorneys

\footnotetext{
260 See infra Part IV.B.

261 Chambliss, supra note 2, at 1754; see RESTATEMENT (THIRD) OF THE LAW GOVERNING LAWYERS $\$ 20 \mathrm{cmt}$. c (2000) ("If the lawyer's conduct of the matter gives the client a substantial malpractice claim against the lawyer, the lawyer must disclose that to the client.").

262 See Restatement (THIRD) OF THE LAW GOVERNING LAWYERS § 20 (3) ("A lawyer ... must explain a matter to the extent reasonably necessary to permit the client to make informed decisions regarding the representation.").

263 See infra Part IV.B.1 (posing the question: "If it becomes clear that the outside client may sue the firm for malpractice, does that development ipso facto create an actual conflict of interest requiring the firm to obtain the client's consent before conducting internal consultations between the attorneys representing the client and the firm's in-house counsel about the malpractice issue?"); infra Part IV.B.2 (asking: "If an actual conflict of interest arises but the firm fails to obtain the outside client's consent to internal consultations about the potential malpractice claim, does the failure preclude the firm from later claiming an attorney-client privilege covering the consultations?").
} 
Representing the Client and the Firm's In-House Counsel About the Malpractice Issue?

One of the recurring themes in the cases advocating the traditional, majority view is that when the outside client indicates that it contemplates suing the firm for malpractice, an actual conflict of interest arises between the client and the firm. The Koen decision is a case in point. Early in the opinion, the court pointed to the conflict of interest rules set out in Pennsylvania Model Rule of Professional Conduct 1.7, modeled after the A.B.A. Model Rule. ${ }^{264}$ The court found that when the firm members representing the Koen company sought legal advice from "another lawyer inside the firm" about the company's potential claim, a conflict arose that "vitiated" any privilege claim by the firm. ${ }^{265}$ Likewise, the earlier Sunrise court relied on Rule 1.7 as an essential premise of its decision. 266

Given the central role of the conflict rules under the majority view, it is important to examine the precise terms of Model Rule 1.7. Rule 1.7(a) identifies the situations in which a disqualifying conflict exists. The current version of Rule 1.7(a) provides:

(a) Except as provided in paragraph (b), a lawyer shall not represent a client if the representation involves a concurrent conflict of interest. A concurrent conflict of interest exists if:

(1) the representation of one client will be directly adverse to another client; or

(2) there is a significant risk that the representation of one or more clients will be materially limited by the lawyer's responsibilities to another client, a former client or a third person or by a personal interest of the lawyer. ${ }^{267}$

The official Comments to Rule 1.7 elaborate on the meaning of the provisions. For instance, Comment 6 explains that (a)(1) comes into play when the lawyer "act[s] as an advocate in one matter against a person

\footnotetext{
264 Koen Book Distribs. v. Powell, Trachtman, Logan, Carrle, Bowman \& Lombardo, P.C., 212 F.R.D. 283, 285 (E.D. Pa. 2002).

265 Id.

266 In re Sunrise Sec. Litig., 130 F.R.D. 560, 597-98 (E.D. Pa. 1989); Chambliss, supra note 2, at 1735-36; Sadler, supra note 10 , at 872 .

267 MODEL RULES OF PROF'L CONDUCT R. 1.7(a) (2012).
} 
the lawyer represents in some other matter." 268 Comment 8 elaborates on $(\mathrm{a})(2)$ :

Even where there is no direct adverseness, a conflict of interest exists if there is a significant risk that a lawyer's ability to consider, recommend or carry out an appropriate course of action for the client will be materially limited as a result of the lawyer's other responsibilities or interests. For example, a lawyer asked to represent several individuals seeking to form a joint venture is likely to be materially limited in the lawyer's ability to recommend or advocate all possible positions that each might take because of the lawyer's duty of loyalty to the others. The conflict in effect forecloses alternatives that would otherwise be available to the client. The mere possibility of subsequent harm does not itself require disclosure and consent. The critical questions are the likelihood that a difference in interests will eventuate and, if it does, whether it will materially interfere with the lawyer's independent professional judgment in considering alternatives or foreclose courses of action that reasonably should be pursued on behalf of the client. ${ }^{269}$

Commenting on the definition of conflict of interest in the analogous Sixth Amendment context, the Court of Appeals for the Eighth Circuit stated that the key to finding a conflict is identifying a plausible alternative strategy that the competing interest might prompt the attorney not to pursue. 270

How do the conflict rules apply to the scenario in which the outside client is threatening to sue or suing the firm for malpractice? If the outside client has already filed a malpractice lawsuit against the firm, there certainly is an actual conflict of interest between the outside client and the firm under Rule 1.7(a)(1); they are the named, opposing plaintiff and defendant in the same lawsuit.

However, when the outside client has not yet filed suit but has threatened to sue, Rule 1.7(a)(2) does not dictate the conclusion that there is already a conflict. Assume, for example, that the outside client

\footnotetext{
268 Id. at R. $1.7 \mathrm{cmt} .6$.

269 Id. at R. $1.7 \mathrm{cmt} .8$.

270 Plunk v. Hobbs, 719 F.3d 977, 981 (8th Cir. 2013) (citing Noe v. United States, 601 F.3d 784, 790 (8th Cir. 2010)).
} 
expresses its dissatisfaction with the firm's services very late in the representation-after pretrial discovery has closed, after trial has been scheduled, after the judge has entered his or her pretrial order including the parties' final stipulations, after the two sides have submitted their formal witnesses lists, and after the opposition has indicated that it is no longer interested in pursuing settlement negotiations. ${ }^{271}$ The outside client's grumbling undeniably creates a tension between the client and the firm, but in the words of Comment 8 "the critical question[]" is whether the firm's concern about the malpractice claim could affect its "professional judgment in considering alternative[]" strategies. ${ }^{272}$ At this late point in the litigation, the firm may have no alternatives; as a practical matter the firm is locked into a theory of the case and a set of witnesses with which to establish that theory. No matter how explicit the outside client's threat to later sue for malpractice if the firm loses, unless it withdraws the firm's only option is to pursue its chosen strategy - to prevail on that theory of the case and hopefully moot the malpractice issue.

The analysis becomes more complex, though, if the outside client raises the possibility of a malpractice action earlier in the litigation when the firm members representing the client still have a choice among alternative strategies. Even then, though, there is not necessarily a disqualifying conflict. A conflict arises only when there is a plausible "link[]" between the firm's alleged neglect and the firm's choice among the alternative strategies for representing the outside client. ${ }^{273}$ Suppose, for example, that the outside client contends that the firm was negligent in preparing to depose an opposing expert. The client asserts that the firm attorneys deposing the expert were woefully unprepared and wasted the time and money attributable to the deposition. However, the opposing litigant later announces that it does not intend to call that expert at trial. The outside client may have a malpractice claim against the firm to recover the fees paid in connection with the deposition, and the client's threat to press the claim unquestionably introduces an element of tension in the relationship between the client and the firm. Yet, since that expert will not appear at trial, it is hard to see how that tension can influence the firm's selection of strategies or tactics for representing the client. Tension or not, without more there does not appear to be a disqualifying conflict under Model Rule 1.7(a)(2).

\footnotetext{
271 E.g., Breezevale, Ltd. v. Dickinson, 759 A.2d 627, 631-32 (D.D.C. 2000), vacated, 769 A.2d 133 (D.D.C. 2001).

272 MODEL RULES OF PROF' L CONDUCT R. 1.7 cmt. 8 (2012).

273 Plunk, 719 F.3d at 981 (quoting Noe v. United States, 601 F.3d 784, 790 (8th Cir. 2010)).
} 
However, varying the facts again, now suppose that the opposing litigant does not withdraw the expert. Rather, as trial approaches, it becomes evident that the opposition views that expert as its star witness. Moreover, assume that on the eve of trial, the firm realizes that there are several different ways of attempting to undermine the expert's testimony. ${ }^{274}$ One of the possible modes of attack is the type of impeachment that the firm used unsuccessfully at the expert's pretrial deposition. Again, the outside client has indicated that it believes that the firm attorneys representing the client were inadequately prepared to develop that impeachment at the deposition. Given the threat of the malpractice claim, the firm might be tempted to resort to that impeachment at trial to show that even if the attack were fully developed, it would not undercut the expert; if the record demonstrated that, the malpractice claim would lack merit. At trial, the firm attorneys could combine that mode of impeachment with other attacks on the expert's testimony, which they believe could succeed. In any event, in this variation of the scenario, the spectre of the malpractice lawsuit might influence the firm's choice among alternative strategies and could, thus, create a genuine conflict of interest. At the very least, that possibility could impact the attorney's advice concerning the advisability of settlement. ${ }^{275}$

2. If an Actual Conflict of Interest Arises but the Firm Fails to Obtain the Outside Client's Consent to Internal Consultations About the Potential Malpractice Claim, Does the Failure Preclude the Firm from Later Claiming an Attorney-Client Privilege Covering the Consultations?

While Model Rule 1.7(a) identifies the situations in which the lawyer has an otherwise disqualifying conflict, Rule 1.7(b) states the consequences of the existence of a conflict. ${ }^{276}$ Rule 1.7(b) prescribes the requirements for the lawyer's continued representation of the client. Rule 1.7(b) reads:

274 See generally EDWARD J. IMWINKELRIED, THE METHODS OF ATTACKING SCIENTIFIC EVIDENCE (5th ed. 2014) (providing a detailed analysis of the methods of attacking "the admissibility, weight, and legal sufficiency of opposing expert testimony").

275 See, e.g., Breezevale Ltd., 759 A.2d at 632 (setting forth the client's argument that advising settlement without informing the client of the firm's conflict of interest constituted malpractice).

276 See MOdel Rules OF PROF'L CONDUCT R. 1.7(b) (2012) (providing instances where an attorney may represent a client despite a concurrent conflict); supra text accompanying note 267 (setting forth the text of Rule 1.7(a)). 
Notwithstanding the existence of a concurrent conflict of interest under paragraph (a), a lawyer may represent a client if:

(1) the lawyer reasonably believes that the lawyer will be able to provide competent and diligent representation to each affected client;

(2) the representation is not prohibited by law;

(3) the representation does not involve the assertion of a claim by one client against another client represented by the lawyer in the same litigation or other proceeding before a tribunal; and

(4) each affected client gives informed consent, confirmed in writing. 277

Rule 1.7(b)(2) and (3) do not require extended comment. Without more, (b)(2) does not apply in the situation in which the outside client has indicated that it might later sue the firm for malpractice, as Comment 16 to Rule 1.7 explains that (b)(2) applies only in extreme situations such as when a lawyer seeks to represent more than one defendant in a capital case. ${ }^{278}$

Similarly, (b)(3) is inapposite. In the words of Comment 17, at the point when the outside client threatens, but has not filed a claim, the outside client and firm are not yet "aligned directly against each other in the same litigation or other proceeding." 279 For that matter, consistently with (b)(1) if the firm "reasonably believes" that it can provide the outside client with "competent... representation" against the outside client's opponent, even that provision does not bar the firm's continued representation of the outside client. 280

By process of elimination, (b)(4) emerges as the decisive issue: Did the firm obtain the outside's client's express consent? What exactly does the client need to consent to? In this setting, the firm supposedly must obtain the outside client's consent that the firm members representing the client confer with in-house firm counsel, ${ }^{281}$ and it must obtain that counsel's legal advice about the appropriate course of action in light of

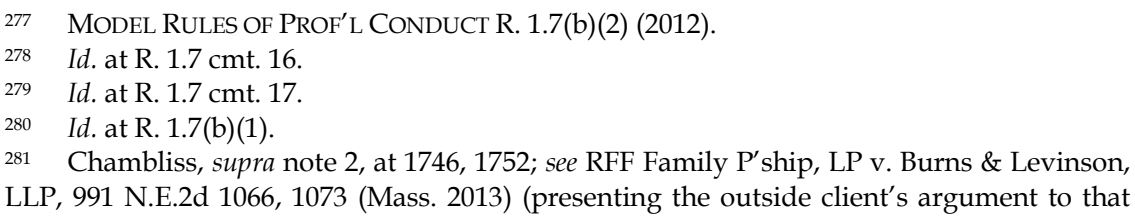


the threatened malpractice claim. ${ }^{282}$ Given the asserted requirement for consent, several practical and legal issues arise.

After concluding that the firm might have committed malpractice, why might the outside client want the firm to continue to represent the client? The lawyer-client relationship is simply one type of human relationship. Persons and companies standing in relationships often decide to continue the relationship after encountering "bumps in the road." Spouses do so, employers and employees do so, doctors and patients do so, and businesses in contractual relationships do so. Even after a minor breach by the other contracting party, a business might conduct a cost/benefit analysis and conclude that the long-term economic value of maintaining the contract far exceeds the paltry amount of damage caused by the minor breach.

In this context, it is easy to conceive of realistic circumstances in which the outside client would desperately want the firm to continue the representation. It could be a foolish, knee-jerk reaction for the outside client to terminate the firm as soon as the client concludes that the firm has committed an act of malpractice. Assume that the law firm has more expertise at this type of transaction or litigation than any other firm, the firm has spent months or years collecting the facts and conducting the relevant legal research, and the hour is late-the trial is scheduled to begin soon, or the other party to the business transaction has signaled that it wants to conclude the negotiations shortly. All those factors could pressure the outside client to favor the continuation of the representation by the firm.

Even if the client consents, why would the firm opt to continue the representation of the client rather than seeking to withdraw and beginning preparations to defend any malpractice action? At first blush, one might think that the path of caution for the firm would be to attempt to withdraw "at the first hint of a problem" 283 and then commence in earnest preparations for any subsequent malpractice action. However, by doing so, the firm would lose its opportunity to mitigate any harm to the client ${ }^{284}$ and thereby minimize the amount of damages it might have to pay as a result of any subsequent malpractice judgment. In many, if not most, cases, the firm can render the malpractice issue moot by achieving a favorable outcome for the client in the transaction or litigation. Especially if the firm has special expertise in the area and has already devoted months or years to assembling the relevant facts, the

\footnotetext{
282 See RFF Family P'ship, 991 N.E.2d at 1072 (discussing the importance of such communication).

283 Chambliss, supra note 2, at 1747.

$284 \quad I d$.
} 
firm might quite sensibly conclude that it is in a much better position than any other law firm to achieve a successful result for the client.

The interplay of the practical consideration described in the preceding three paragraphs ultimately leads to the decisive legal issue: If (1) the outside client does not terminate the firm but withholds consent to the firm's in-house consultations; and (2) the firm does not withdraw and decides to conduct the in-house consultations, does the client's lack of consent preclude the attorney-client privilege from attaching to the consultations? In this variation of the situation, will the firm altogether forego any privilege if the firm decides to conduct the consultations despite the client's refusal to consent?285 There is a strong case that in most cases, the answer to that question should be no.

Assume arguendo that the firm's conduct constitutes an ethical violation of Model Rule 1.7(b). As the Georgia Supreme Court noted in its 2013 decision, the question of the applicability of the attorney-client privilege is governed by evidence laws, not legal ethics. ${ }^{286}$ In Georgia, as in many states, the history and text of the state ethical rules make it clear that the ethical rules "'are not intended to govern or affect judicial application of ... the attorney-client ... privilege.'" 287

In passing, in their opinions, both the Ninth Circuit in Rowe and the Georgia court briefly mentioned the evidentiary doctrine that arguably controls here-the crime/fraud exception to the attorney-client privilege. ${ }^{288}$ Unfortunately, to date neither the cases applying the traditional view nor those espousing the minority view have undertaken a thorough analysis of the applicability of that exception to this fact situation. As the U.S. Supreme Court has recognized, most recently in United States $v$. Zolin, although the law hopes to encourage legitimate consultations between clients and attorneys, the law does not want to facilitate the commission of crimes and frauds. ${ }^{289}$ Consequently, the privilege does not attach when a client consults an attorney for the primary purpose of obtaining advice to facilitate the commission of an ongoing or future crime or fraud. A proponent of the traditional,

285 Id. at 1743 ("If withdrawal is not possible ... the firm must simply forgo privileged advice altogether."); see Koen Books Distribs. v. Powell, Trachtman, Logan, Carrle, Bowman \& Lombardo, P.C., 212 F.R.D. 283, 286 (E.D. Pa. 2002) (refusing to apply the privilege because the firm could have withdrawn from the proceeding).

286 St. Simons Waterfront, LLC v. Hunter, Maclean, Exley \& Dunn, P.C., 746 S.E.2d 98, 102 (Ga. 2013).

287 Id. at 106 (quoting GA. RULES OF PROF'L CONDUCT, Preamble, q 19 (Westlaw Next current with amendments received through 11/1/2013)).

288 United States v. Rowe, 96 F.3d 1294, 1297 (9th Cir. 1996); St. Simons Waterfront, LLC, 746 S.E.2d at 107.

289491 U.S. 554, 562-63 (1989); see 1 IMWINKELRIED, supra note 9, § 6.13.2.d, at 1166-67 (noting this tension). 


\section{4] Preliminary Thoughts on an Attorney-Client Privilege 753}

majority view denying intra-firm privilege might contend that when the firm conducts in-house consultations without the required consent of the outside client, the crime/fraud exception applies, precluding the recognition of an attorney-client privilege. In many situations, though, that contention will fail.

To begin, most jurisdictions hold that, standing alone, a violation of the legal ethics rules does not constitute a crime or fraud. It is true that jurisdictions vary in their views of the breadth of the exception. ${ }^{290}$ For example, while some states apply the exception only to fraud upon the court, most states extend the exception to any tort of fraud. ${ }^{291}$ However, only a distinct minority of states have expanded the scope of the exception to reach violations of the rules of legal ethics. ${ }^{292}$ Unless the facts underlying the legal ethical violation also constituted either a crime or a tort of fraud, the crime/fraud exception cannot be invoked to defeat a prima facie case for applying the privilege.

To be sure, there are situations in which the facts establishing the legal ethical violation will also make out a case for fraud. It is one thing for the firm to engage in internal consultations despite the outside client's refusal to consent if the firm informs the client that it nevertheless intends to conduct the consultations. It is quite another matter-and a fact situation which would arguably trigger the crime/fraud exception-when the firm members representing the outside client seek the in-house counsel's advice as to how to conceal the consultations from the client. As Professor Chambliss interprets the facts in Bank Brussels, there the firm attorneys representing the client "sought... [the] advice" of the head of the firm's Clients and Ethics Committee "primarily in order to conceal the conflict." 293 She correctly concludes that this type of misconduct is tortious and fraudulent. ${ }^{294}$

However, facts as extreme as those in Bank Brussels are presumably atypical. In a run-of-the-mill case, the firm seeking to invoke the privilege can forthrightly inform the outside client that even without the client's blessing, the firm members representing the client intend to consult with in-house counsel about defensive measures in anticipation of a malpractice claim. ${ }^{295}$ Of course, at that juncture the client is free to

\footnotetext{
290 See 1 IMWINKELRIED, supra note 9, §6.13.2.d(1), at 1170-75 (exploring splits in authority).

291 See $i d$. $\S 6.13 .2 . d(1)$, at 1172 (stating that the majority of jurisdictions construe fraud "broadly").

$292 \quad$ Id. $\S 6.13 .2 . \mathrm{d}(2)$, at 1175

293 Chambliss, supra note 2, at 1751.

294 Id.

295 St. Simons Waterfront, LLC v. Hunter, Maclean, Exley \& Dunn, P.C., 746 S.E.2d 98, 104-05 (Ga. 2013).
} 
terminate the firm even if the client did not fire the firm earlier when the client initially discovered the possible malpractice claim. Moreover, as the Georgia Supreme Court noted, it is conceivable that, although the privilege would apply to the consultations, the firm would be guilty of an ethical violation. ${ }^{296}$ However, there is no logical necessity for legal ethics rules to dictate evidentiary doctrine. In its opinion, the Massachusetts Supreme Judicial Court deemed it significant that in the lengthy list of thirteen different judicial remedies for a lawyer's breach of ethical duties in the Restatement (Third) of the Law Governing Lawyers, there is no mention of denial or forfeiture of privilege as a sanction. ${ }^{297}$

\section{CONCLUSION}

There is unanimity that the members of a law firm owe a fiduciary duty of loyalty to the firm's outside clients. However, "fiduciary" is not a talisman that makes the firm's legitimate interests and rights vanish. The firm has substantial reputational and financial interests that justify the protection of the attorney-client privilege when the firm has made it clear that it is the client of an in-house firm counsel and the firm has been candid in its dealings with the outside client. No human relationship is perfect. It is to be expected that even after the persons or entities voluntarily form a trusting, cooperative attorney-client relationship, the client will sometimes conclude that the attorney has breached its duties to the client-even when the client decides against immediately terminating the relationship.

To be sure, when the relationship continues, the outside client has a right to expect competent legal service during the balance of the representation. Moreover, the client does not waive the potential malpractice claim by retaining the firm. For that matter, while the relationship survives, the outside client is obviously free to hire a second law firm to begin developing the malpractice case against the firmwhich is precisely what SSW did in the Georgia case. ${ }^{298}$ No one would deny that SSW enjoyed an attorney-client privilege protecting its consultations with the second firm and that SSW could have asserted

\footnotetext{
296 Id. at 106 n.4 ("We emphasize that this opinion is not intended to resolve the ethical quandary and instead addresses only the evidentiary questions of privilege ...."). 297 RFF Family P'ship, LP v. Burns \& Levinson, LLP, 991 N.E.2d 1066, 1079 (Mass. 2013). 298 St. Simons Waterfront, 746 S.E.2d at 102 ("SSW retained another law firm ... to pursue potential action against Hunter Maclean; new counsel requested ... that Hunter Maclean continue to handle the ongoing closings, which Hunter Maclean did ....").
} 


\section{4] Preliminary Thoughts on an Attorney-Client Privilege 755}

that privilege against the original firm, Hunter Maclean, in a subsequent malpractice claim against Hunter Maclean. ${ }^{299}$

The key issue is whether Hunter Maclean should be entitled to a similar privilege for the internal consultations that it conducted at the same time SSW was developing its case against Hunter Maclean. So long as a firm such as Hunter Maclean does not mislead the outside client, the firm has a plausible claim that it ought to be free to take prudent steps to protect its interests against the eventuality that a client such as SSW later sues for malpractice. The firm should not be "without recourse" to protect its interests. ${ }^{300}$ In the long term, judicial encouragement of internal consultations between the firm members representing the outside client and experienced firm in-house counsel could result in improved service to outside clients. ${ }^{301}$ Veteran in-house counsel can provide the attorneys representing the outside client with an expert, more objective perspective that, in many cases, will redound to the client's benefit. The traditional, majority view, denying the firm a privilege, creates a significant disincentive for such consultation. The emerging minority view, recently endorsed by the Georgia and Massachusetts courts, is an arguably defensible alternative approach.

As previously stated, this Article offers only a preliminary analysis of these complex issues. Relatively few courts have addressed these issues, and unfortunately in those opinions the analysis of the critical fiduciary and crime/fraud exceptions to the attorney-client privilege has tended to be conclusory. The courts favoring the traditional view have slighted the case law permitting fiduciaries to claim the privilege when they sought counsel after their interests diverged from those of the beneficiary, and for their part the courts championing the minority view have skimmed the surface of the applicability of the crime/fraud exception. Legal malpractice claims are too common and the stakes of the bar and its clientele are too vital to be satisfied with the current split of authority. The hope is that this Article will help prompt a more intense debate over these issues-and a deeper exploration of the relationship between legal ethical duty of loyalty and the attorney-client privilege in evidence law.

\footnotetext{
299 By suing the former firm for malpractice, the client effects a limited waiver of the privilege; and the firm may disclose its communications with the client to the extent necessary to defend the malpractice claim. See generally 1 IMWINKELRIED, supra note 9, $\S$ 6.13.2.a, at 1142-51 (outlining the self-defense exception). However, that waiver does not extend to the client's communications with the new counsel prosecuting the malpractice claim. Fischel \& Kahn, Ltd. v. Van Straaten Gallery, Inc., 727 N.E.2d 240, 244-45 (Ill. 2000).

300 Chambliss, supra note 2, at 1723.

301 See generally id. (discussing the benefits of applying the intra-firm privilege).
} 